\title{
Quaternary fans and terraces in the Khumbu Himal south of Mount Everest: their characteristics, age and formation
}

\author{
PATRICK L. BARNARD ${ }^{1}$, LEWIS A. OWEN ${ }^{2} \&$ ROBERT C. FINKEL ${ }^{3}$ \\ ${ }^{1}$ United States Geological Survey, Pacific Science Center, 400 Natural Bridges Drive, Santa Cruz, CA 95060, USA \\ (e-mail: pbarnard@usgs.gov) \\ ${ }^{2}$ Department of Geology, University of Cincinnati, Cincinnati, OH 45221-0013, USA \\ ${ }^{3}$ Lawrence Livermore National Laboratory, 7000 East Ave, MS L397, Livermore, CA 94550, USA
}

\begin{abstract}
Large fans and terraces are frequent in the Khumbu Himal within the high Himalayan valleys south of Mt. Everest. These features are composed of massive matrix- and clast-supported diamicts that were formed from both hyperconcentrated flows and coarse-grained debris flows. Cosmogenic radionuclide (CRN) exposure ages for boulders on fans and terraces indicate that periods of fan and terrace formation occurred at $c .16, c$. 12, c. 8, c. 4 and c. $1.5 \mathrm{ka}$, and are broadly coincident with the timing of glaciation in the region. The dating precision is insufficient to resolve whether the surfaces formed before, during or after the correlated glacial advance. However, the sedimentology, and morphostratigraphic and geomorphological relationships suggest that fan and terrace sedimentation in this part of the Himalaya primarily occurs during glacier retreat and is thus paraglacial in origin. Furthermore, modern glacial-lake outburst floods and their associated deposits are common in the Khumbu Himal as the result of glacial retreat during historical times. We therefore suggest that Late Quaternary and Holocene fan and terrace formation and sediment transfer are probably linked to temporal changes in discharge and sediment load caused by glacier oscillations responding to climate change. The timing of major sedimentation events in this region can be correlated with fans and terraces in other parts of the Himalaya, suggesting that major sedimentation throughout the Himalaya is synchronous and tied to regional climatic oscillations. Bedrock incision rates calculated from strath terrace ages average $c$. $3.9 \mathrm{~mm} \mathrm{a}^{-1}$, suggesting that the overall rate of incision is set by regional uplift.
\end{abstract}

High Himalayan landscapes provide excellent natural laboratories to examine the interactions between tectonics, surface processes and climate change within an active continent-continent collision zone (Zeitler et al. 2001; Bishop et al. 2002). Furthermore, these regions contain excellent geomorphological and sedimentological records of glacial oscillations that provide important insights into the nature of Late Quaternary palaeoclimate change, notably the glacial and hydrological response to oscillations in the south Asian monsoon (Owen \& Lehmkuhl 2000; Owen \& Zhou 2002; Finkel et al. 2003). As a first step in examining the relationship between climate change and landscape evolution, we focus our study on landforms within the valleys of the Khumbu Himal region, south of Mount Everest (Figs 1 and 2). The region was chosen because it is relatively accessible and has well-established glacial chronologies, and contains abundant impressive fans and terraces that partially fill deep valleys downstream from modern glaciers (Muller 1958, 1980; Iwata 1976; Fushimi 1977, 1978; Williams 1983; Benn \& Owen 1998; Owen et al. 1998; Aoki \& Imamura, 1999; Richards et al. 2000; Finkel et al. 2003). (The fans may be described as 'alluvial fans', but we avoid the use of this term because it implies a genetic (fluvial) origin for the fanshaped landforms that are present within Himalayan valleys. These landforms predominantly comprise diamictons that may be of debris flow, hyperconcentrated flow and/or fluvial origin. We therefore use the non-genetic term 'fan' to describe these landforms.) These landforms (e.g. Fig. 1) allow us to begin to examine in detail the temporal and spatial relationships between climate change, glaciation, sediment transfer, and fan and terrace formation. In this paper, we report our investigations of these fans and terraces to provide evidence for the timing and rates of the erosional and depositional processes within this high Himalayan environment. We suggest temporal and genetic links between terrace and fan formation, and glacier oscillations. Our study of the fans and terraces in the Khumbu Himal and the related study on glacial stages by Finkel et al. (2003) are unique in the large number of samples dated $(>100)$, number of landforms dated (14 fan or terrace surfaces, 15 moraines), great spatial distribution of the sampling (tens of kilometres), and integration with landform sedimentology. This represents the most extensive surface dating project ever attempted in the high Himalaya.

Previous studies suggested that Quaternary fans within the Himalaya formed by rapid sedimentation during times of glacial retreat (Derbyshire \& Owen 1990; Owen et al. 1995; Owen \& Sharma 1998; Watanabe et al. 1998; Barnard et al. 2004a). These studies argued that fan formation occurred during times of glacial retreat and thus could be described as 'paraglacial'. This follows the view of Ryder $(1971 a, b)$ and Church \& Ryder (1972) that major episodes of deposition by non-glacial processes in proglacial environments are conditioned by glaciation. Moreover, Church \& Slaymaker (1989) argued that enhanced sedimentation may persist for many millennia as landscapes adjust to non-glacial conditions. We aim to test these assertions by determining whether the Khumbu fans and terraces are paraglacial in origin and their formation is thus conditioned by climate, which in turn forces glaciation.

\section{Research area}

The Khumbu Himal is located in eastern Nepal, c. $200 \mathrm{~km}$ NE of Kathmandu (Fig. 2 inset). The south Asian summer monsoon is 

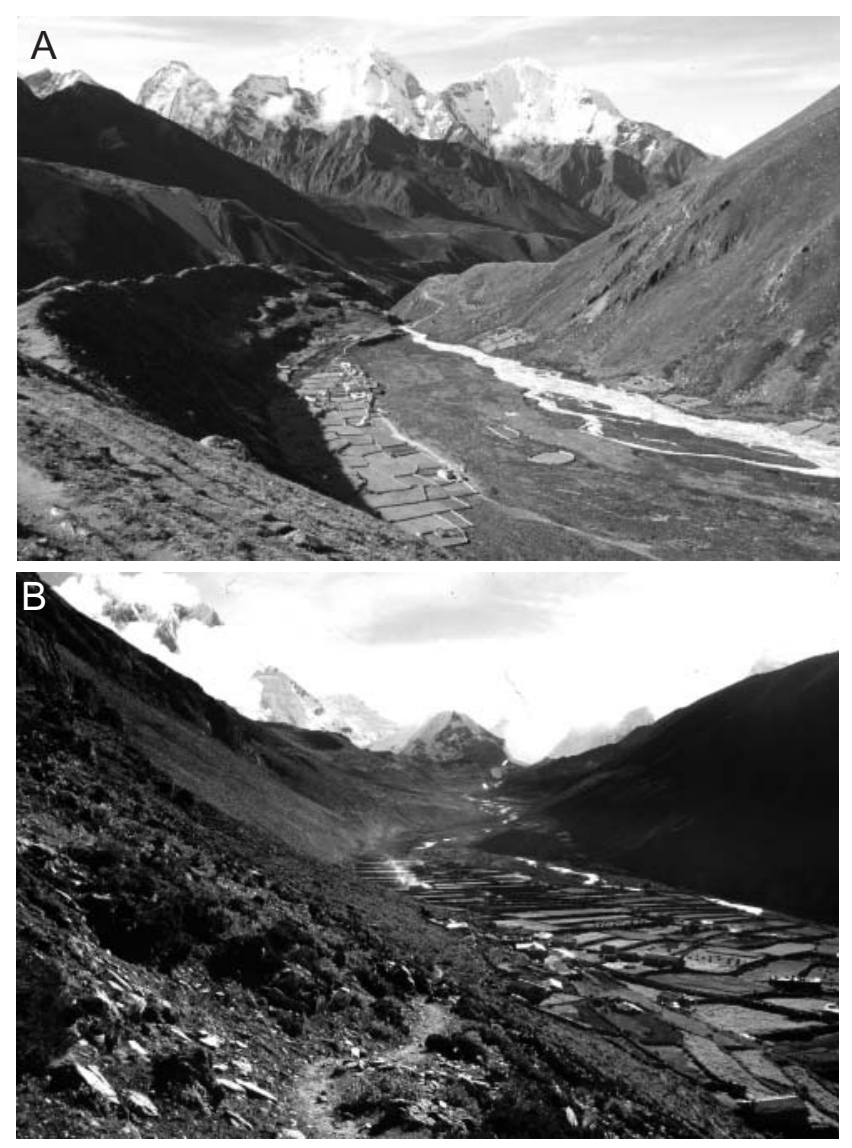

Fig. 1. Typical fans and terraces in the Khumbu Himal. (a) View downvalley of an outwash fan below the Khumbu glacier and a major latero-frontal moraine (middle left) dated to $c .23$ ka by Finkel et al. (2003). (b) View upvalley of a large terrace at Dingboche downvalley of glaciers and moraines at Chhukhung.

the major source of precipitation in the region. A steep precipitation gradient exists across this region because of topographic effects, ranging from $>1500 \mathrm{~mm} \mathrm{a}^{-1}$ at Lukla (2600 $\mathrm{m}$ above sea level (a.s.1.)) in southern Khumbu to $c .435 \mathrm{~mm} \mathrm{a}^{-1}$ at Dingboche (4355 $\mathrm{m}$ a.s.1.) in northern Khumbu, in the vicinity of our research area (Nepal Department of Hydrology and Meteorology 1993, 1995, 1996, 1997). The average annual temperature at Dingboche is $-0.7{ }^{\circ} \mathrm{C}$ (Nepal Department of Hydrology and Meteorology 1993, 1995, 1996, 1997). During the winter months, mid-latitude westerlies transport moisture from the Mediterranean, Black and Caspian Seas toward the Himalaya, but significant snowfall from this source is largely restricted to the western Himalaya (Benn \& Owen 1998). At present, most snowfall in the study area accumulates during the summer when moisture is advected north from the Indian Ocean.

The Khumbu Himal contains more than 50 cirque and valley glaciers. Impressive successions of moraines mark the extent of past glaciers (Richards et al. 2000; Benn et al. 2001; Finkel et al. 2003). Building on the work of Richards et al. (2000), Finkel et al. (2003) documented, using cosmogenic radionuclide (CRN) surface exposure dating, eight separate glacial advances during the Pleistocene and Holocene. These comprise: Thyangboche I (86 $\pm 6 \mathrm{ka})$, Thyangboche II ( $35 \pm 3 \mathrm{ka})$, Pheriche I ( $23 \pm 3 \mathrm{ka})$, Pheriche II (16 $\pm 2 \mathrm{ka})$, Chhukhung $(9.2 \pm 0.2 \mathrm{ka})$, Thuklha $(3.6 \pm 0.3 \mathrm{ka})$, Lobuche $(c .1 \mathrm{ka})$ and Historical $(<0.5 \mathrm{ka})$. Their results indicate that major glacier advances, such as the Chhukhung Stage, are synchronous with insolation maxima, when increased precipitation delivered by the south Asian summer monsoon fell as snow at high altitudes despite the higher summer temperatures and led to a positive glacial mass balance. During periods of major global cooling, the south Asian summer monsoon was significantly weakened (Sirocko et al. 1991), reducing precipitation in the Himalaya. Nevertheless, in some cases, such as during the Pheriche Stages, temperatures were lowered sufficiently to allow glaciers to advance, albeit to a restricted extent (Owen et al. 2002a; Finkel et al. 2003).

\section{Field methods}

Three detailed study areas were chosen in the upper catchment of the Khumbu Himal for geomorphological mapping, stratigraphic analysis and CRN dating. These include, in order of increasing altitude up valley: Pangboche, Orsho and Dingboche (Fig. 2). The three study areas contain the most extensive and best-preserved fan successions in the upper Imja Khola Valley, as well as excellent sites for CRN dating, exposed sedimentary sections and well-preserved moraines.

In each area, we used geomorphological and topographic mapping as well as cross-valley profiles to determine the size and relative ages of the fans, terraces and other features. Fans (f) and terraces (t) are designated herein by their morphology and stratigraphic position; for example, $t_{\mathrm{p} 1}$ is a terrace where the subscript letter refers to the location ( $p$, Pangboche; o, Orsho; d, Dingboche) and the subscript number refers to the relative terrace age (1, youngest; 7 , oldest). This mapping also allowed us to reconstruct the former extent of fan and terrace deposits prior to erosion. Sedimentary sections were logged at natural exposures to examine the sediments. Where fan surfaces were not contiguous, correlations were based on relative elevations.

The fans and terraces in the study areas all originate from glacial drainages and have similar morphology and sedimentology, with planar surfaces and coarse diamict deposits. Fans are distinguished from terraces on the basis of slope and position. The Khumbu fans are associated with steep side valley channels and generally have slopes $>7^{\circ}$. Terraces have slopes $<7^{\circ}$, whereas the terraces are associated with the main trunk valleys.

\section{Dating}

A total of 56 samples for CRN dating were collected from the three study sites. Samples were obtained from fan and terrace surfaces, as well as from three modern surfaces. Landforms for CRN dating were chosen to represent the entire chronological range of preserved Quaternary surfaces in the region. The most common rock type sampled was leucogranite. Samples were typically taken from boulder surfaces lying at least $1 \mathrm{~m}$ above the fan or terrace surface (to avoid exhumed boulders) and along the distal edges of the landform where the potential complicating effects of erosion, burial, rock fall, or agricultural activity are lowest. A commonly recognized problem with CRN dating is that a sampled boulder may retain a signal of prior exposure inherited from its previous location (i.e. 'derived' boulders: Anderson et al. 1996; Hancock et al. 1999). To help recognize derived boulders, we collected multiple samples from each fan or terrace and looked for potential outliers, that is, exposure ages that fell significantly outside the weighted mean of the landform dated. A second way in which we checked for the possibility of inheritance was to date clasts from the modern floodplain to see whether they gave very low ages (see Anderson et al. 1996). We sampled two sand samples from Orsho (E22) and Dingboche (E120), and a boulder along the Orsho floodplain (E21). Dating samples from a landform of known age allowed us to further test the role of inheritance. A flood terrace at Pangboche, $\mathrm{t}_{\mathrm{p} 2}$, for example, which was deposited in 1977, provided an excellent zero-age surface (Ives 1986; Zimmermann et al. 1986; Cenderelli \& Wohl 2001). Another problem is boulders that produce erroneously young CRN ages. This is probably caused by boulders that have been exhumed or toppled. We reduce the potential of 


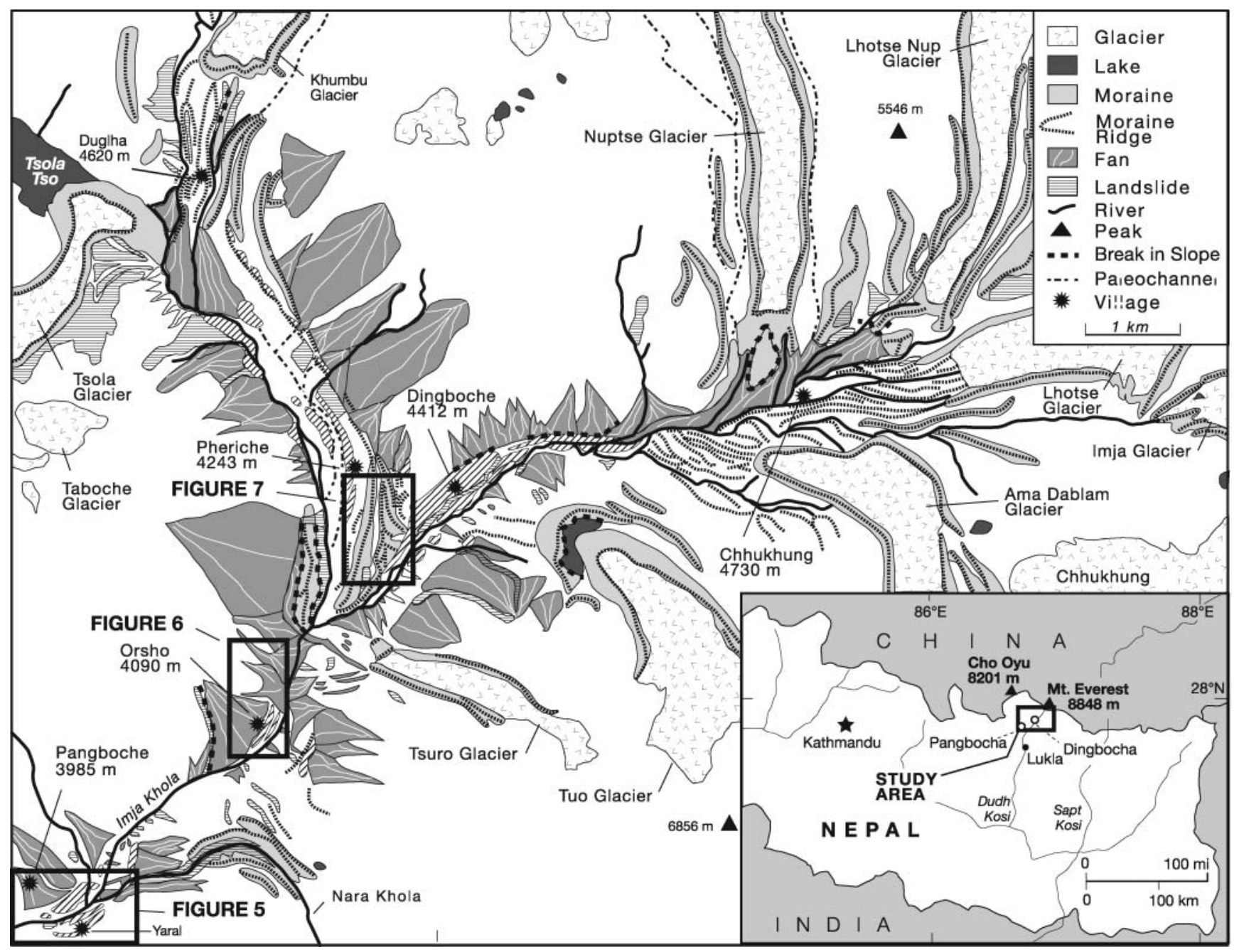

Fig. 2. Geomorphological map of the upper Imja Khola Valley, Khumbu Himal. Boxes define study areas. Mapped at a scale of 1:25000.

exhumation by choosing the largest boulders on each surface, sampling on ridges (not depressions) on a landform surface, choosing boulders with at least $1 \mathrm{~m}$ of relief, and sampling the highest point on each boulder surface. The potential for sampling toppled boulders is reduced by choosing boulders on the distal edges of a landform to avoid toppling from higher surfaces and by sampling boulders that appear well embedded in the landform surface.

In addition to sampling depositional surfaces, one sample was collected for CRN dating from each of four strath terraces lying between 14 and $55 \mathrm{~m}$ above the current level of the Imja Khola, $1 \mathrm{~km}$ SW of Pangboche.

The CRN samples were analysed for ${ }^{10} \mathrm{Be}$ content in quartz at Lawrence Livermore National Laboratory. First, the samples were crushed and sieved. Quartz was then separated from the $250-500 \mu \mathrm{m}$ size fraction using the method of Kohl \& Nishiizumi (1992). After addition of Be carrier, Be was separated and purified by ion exchange chromatography and precipitation at $\mathrm{pH}>7$. The hydroxides were oxidized by ignition in quartz crucibles. $\mathrm{BeO}$ was then mixed with $\mathrm{Nb}$ metal prior to determination of the ${ }^{10} \mathrm{Be} /{ }^{9} \mathrm{Be}$ ratios by accelerator mass spectrometry at the Center for Accelerator Mass Spectrometry in the Lawrence Livermore National Laboratory. Isotope ratios were compared with ICN Pharmaceuticals Inc ${ }^{10} \mathrm{Be}$ standards prepared by K. Nishiizumi (pers. comm.) using a half-life of $1.5 \times 10^{6}$ a. Age determinations were based on the equations and production rates given by Lal (1991) as modified by Stone (2000). A correction for variation in the geomagnetic field was applied to determine the final age of each sample as described by Nishiizumi et al. (1989) using the SINT800 geomagnetic intensity assessment (J.-P. Valet, pers. comm.). Full details of the methods used in the age determination have been given by Owen et al. $(2001,2002 b)$.

\section{Fan geomorphology and sedimentology}

With the exception of modern surfaces, each fan and terrace has been incised and partly eroded by progressive downcutting, resulting in nested successions of fans and terraces. The fan and terrace deposits comprise massive beds (2-85 $\mathrm{m}$ thick) of matrix-supported cobbles and matrix- and clast-supported boulders. The bouldery diamicts generally have isotropic clast fabrics, but with localized zones of imbrication. The clasts are normally subangular with edges rounded to subrounded, and constitute more than $c$. $50 \%$ of the sediment. Clast sizes typically range from 0.5 to $2 \mathrm{~m}$, with some exceeding $5 \mathrm{~m}$ in diameter. More than two diamict units are rare in a single exposure. The deposits are indurated and the boulders are transitional between being clast-supported and matrix-supported by pebbly sand with very little silt $(c .<10 \%)$. The cobbly diamicts have clast fabrics with weak to moderate downvalley-preferred orientation. The clasts are subrounded, making up c. $20 \%$ of the solid fraction, and are supported by a matrix of pebbly sand, with little silt and clay present $(c .<5 \%)$. The cobbly diamicts are poorly sorted, 
massive and moderately friable. In some deposits the beds are slumped and crudely stratified. Dominant clast sizes range from 10 to $20 \mathrm{~cm}$.

\section{Pangboche-Yaral}

We identified 10 distinct fan or terrace levels in the PangbocheYaral area. Nine of the 10 surface levels identified are shown in Figure 3, and five surfaces can be traced across the valley (top to bottom: $t_{p 7}, t_{p 6}, t_{p 3}, t_{p 2}$, modern floodplain) (Fig. 3). The upper three levels are fans, which are steeply sloping $\left(>11^{\circ}\right)$ and have abundant large boulders $(>5 \mathrm{~m})$ on their surfaces. The fan of greatest surface area, $\mathrm{t}_{\mathrm{p} 6}$, on the Pangboche side of the valley, is formed of cobbly diamicts overlain by bouldery diamicts transitional between matrix- and clast-supported (Fig. 4). The lower five surfaces are terraces on the Pangboche side of the valley that are inset into the largest fan, and slope parallel to the main valley axis. The lower bouldery terrace surfaces $\left(t_{p 2}\right.$ and $\left.t_{p 3}\right)$ in the Pangboche-Yaral area comprise mostly boulders and are sparsely vegetated (Fig. 5). Sections in $t_{\mathrm{p} 3}$ show bouldery diamicts, with subangular clasts, some imbrication, and no bedding. The downstream tongue of the surface of $t_{\mathrm{p} 3}$ consists primarily of moderately well-sorted and subrounded, clast-supported boulders (c. $1 \mathrm{~m}$ in diameter), with large pore spaces $(>10 \mathrm{~cm}$ in diameter; Fig. 5c).

Terrace $t_{\mathrm{p} 2}$ is a fresh boulder deposit with a surface mantled with megaripples (wavelength $c .2-3 \mathrm{~m}$ ), flood chutes and scour pits. This surface formed from a glacial-lake outburst flood that started $8 \mathrm{~km}$ upstream on 3 September 1977, when a series of ice-cored moraine dams failed below the Nare Glacier and flood waters surged down the Nare Khola Valley toward Pangboche (Cenderelli \& Wohl 2001).

A set of four nested fans and terraces $\left(f_{p 3}, f_{p 2}, t_{p 7}\right.$ and $\left.t_{p 6}\right)$ originate from the small side valleys above Pangboche village on the Pangboche side of the Imja Khola valley. Additional lower surfaces (i.e. $t_{\mathrm{p} 5}$ to $t_{\mathrm{p} 1}$ ) are aligned with the main valley axis, having originated as sediments from further up the Imja Khola valley (trunk valley). On the Yaral side, only $\mathrm{f}_{\mathrm{p} 1}$ emerges from a small side valley, originating from a cirque glacier high atop the valley floor. The fan sediments on the Yaral side have their origin from the glaciated valley to the east, the Nare Khola, which drains two glaciers along the southern flanks of Ama Dablam.

Despite being morphostratigraphically equivalent, not all fan levels that are apparently matched on both sides of the valley at Pangboche and Yaral originate from the same source region. This is the case for both surfaces $t_{p 6}$ and $t_{p 7}$, where directions of maximum slope on each surface demonstrate that sediment on the two fans on the Pangboche side of the valley originates from two side valleys to the north of the region, whereas the equivalent fans on the Yaral side originate from the Nare Khola Valley to the east. However, the similar elevations and nearly identical sediment types indicate that the fans formed under similar conditions at or about the same time.

\section{Orsho}

A prominent set of abandoned fan and terrace surfaces are present at Orsho (4070 $\mathrm{m}$ a.s.1.), $3 \mathrm{~km}$ up valley from Pangboche (Figs 2 and 6). The Orsho landform succession is located immediately below a large terminal moraine complex of the Khumbu Glacier (Fig. 1a).

A steeply sloping $\left(19-23^{\circ}\right)$ upper fan $\left(f_{01}\right)$ and six gently sloping lower terraces $\left(4-5^{\circ}\right)$ are preserved on the western side of the valley (Fig. 6). Active slope processes have destroyed or covered fan and terrace deposits on the eastern side of the valley at Orsho. The overall geometry of the Orsho surfaces and their sedimentology are similar to those at Pangboche.

The fan $\left(f_{o 1}\right)$ is the only surface whose axis is perpendicular to the main valley slope. It formed at the foot of a valley that is fed by outwash from the Taboche Glacier (Fig. 2). The lower terrace surface axes are all aligned with the main valley axis and their slopes approximate the main valley slope, indicating sedimentation originating from further up the Imja Khola Valley.

\section{Dingboche}

Dingboche is located immediately downvalley from the glacial complex at Chhukhung, which consists of seven converging glaciers. The Dingboche area is highly susceptible to sedimentation events even during periods of only moderate glacial fluctuation because of its upvalley location, near the present glacier margins. A succession of latero-frontal moraines is located up the Imja Khola valley, $2.5 \mathrm{~km} \mathrm{NE}$ of Orsho (Figs 1a and 2). These represent the former terminus of the Khumbu and Chhukhung glaciers during the Pheriche I (23 $\pm 3 \mathrm{ka})$ and Pheriche II (16 $\pm 2 \mathrm{ka})$ Glacial Stages (Richards et al. 2000; Finkel et al. 2003). An extensive axial terrace, $t_{\mathrm{d} 3}$, grades to the outermost moraine complex near the village of Dingboche (Fig. 7). Two large terraces, $t_{d 2}$ and $t_{d 1}$, are present further up the valley toward Chhukhung but are morphostratigraphically lower and younger than the largest Dingboche surface $\left(t_{d}\right)$. The Dingboche surfaces are much broader and at lower elevations relative to the valley bottom than those at Orsho and Pangboche, probably because the Chhukhung glacier extended into and beyond this region, most recently during the Late Pleistocene (16 $\pm 2 \mathrm{ka}$; Finkel et al. 2003), widening the valley and thus creating extra space for subsequent sedimentation.

Thin $(<3 \mathrm{~m})$ bouldery and cobbly diamict units dominate the exposed sediment sections in the terraces at Dingboche. However, channel deposits are also present, such as a thin sandy pebble layer that is present in a section from $t_{d 1}$ (Fig. 8). Furthermore, clean fine sand is also present in sections examined in $t_{d 1}$, and this probably represents wind-blown sediment from nearby glacial deposits accumulating during the dry periods following glacial stages.

\section{Dating results}

An estimate of the age of each fan and terrace surface was determined by calculating the weighted average of the individual exposure ages for each surface using the analytical uncertainty as a weighting factor. Factors other than analytical uncertainty can contribute to the spread of ages on a surface. For example, storm events can dislodge samples from higher surfaces and overbank flow can deposit samples from younger, lower-lying landforms. Therefore, samples yielding exposure ages that were within the range of dates determined from surfaces above or below the surface or significantly different from the general population for the given surface, were not included in the calculation. Ages for 16 fan and terrace surfaces were then determined based on 47 CRN dates (Table 1, Fig. 9). In this study we took only three or four samples from each surface to obtain a sufficient number of dates to allow us to develop a broad framework for the Late Quaternary fan and terrace depositional history of the Khumbu. The small number of samples gathered from each surface precludes calculating statistically significant average ages for each surface, but the breadth of coverage allows us to make general conclusions about the temporal development of fans and 

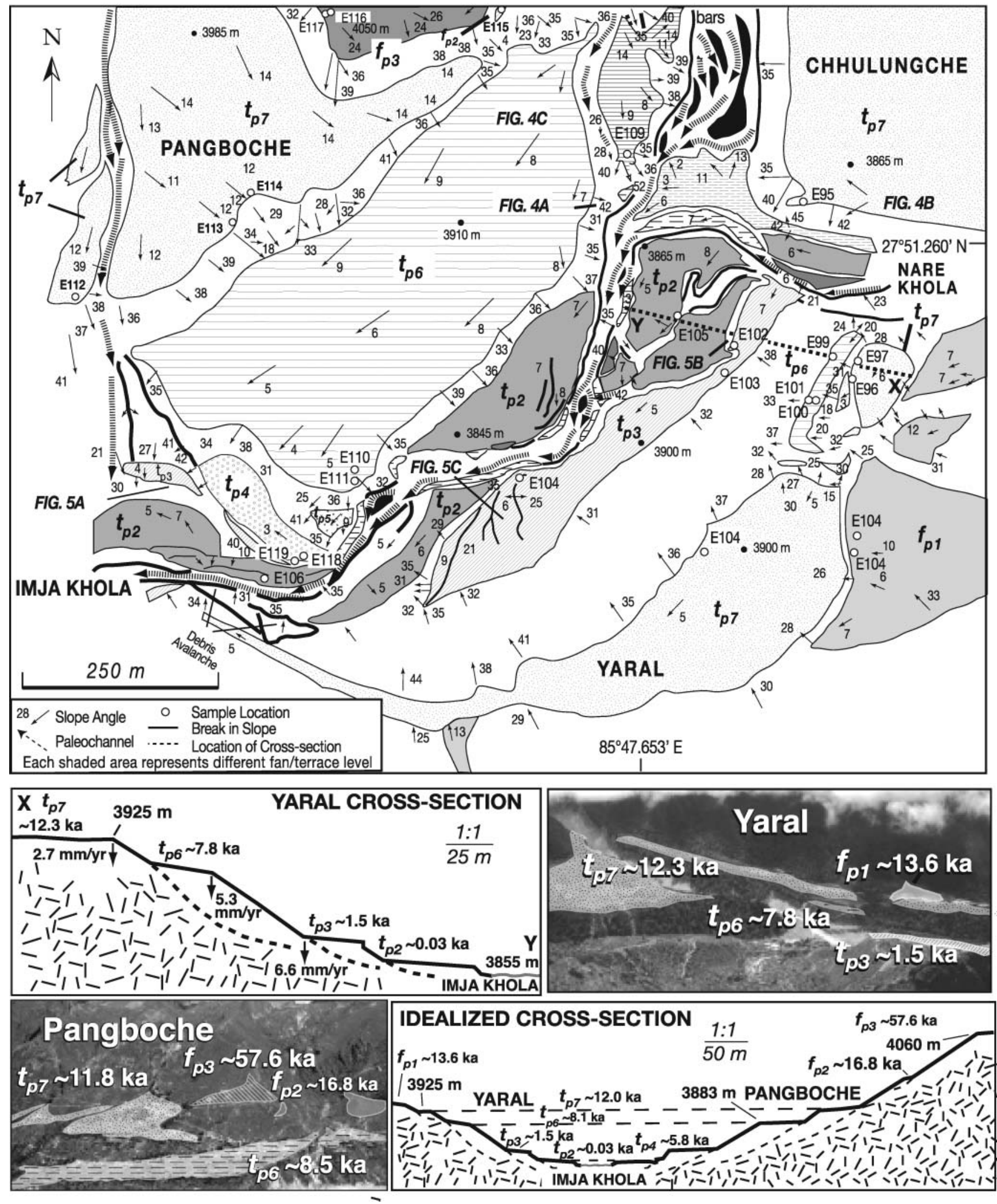

Fig. 3. Geomorphological map of the Pangboche-Yaral study area showing valley profiles and sampling sites. Mapped at a scale of 1:5000. No vertical exaggeration for the cross-sections. 

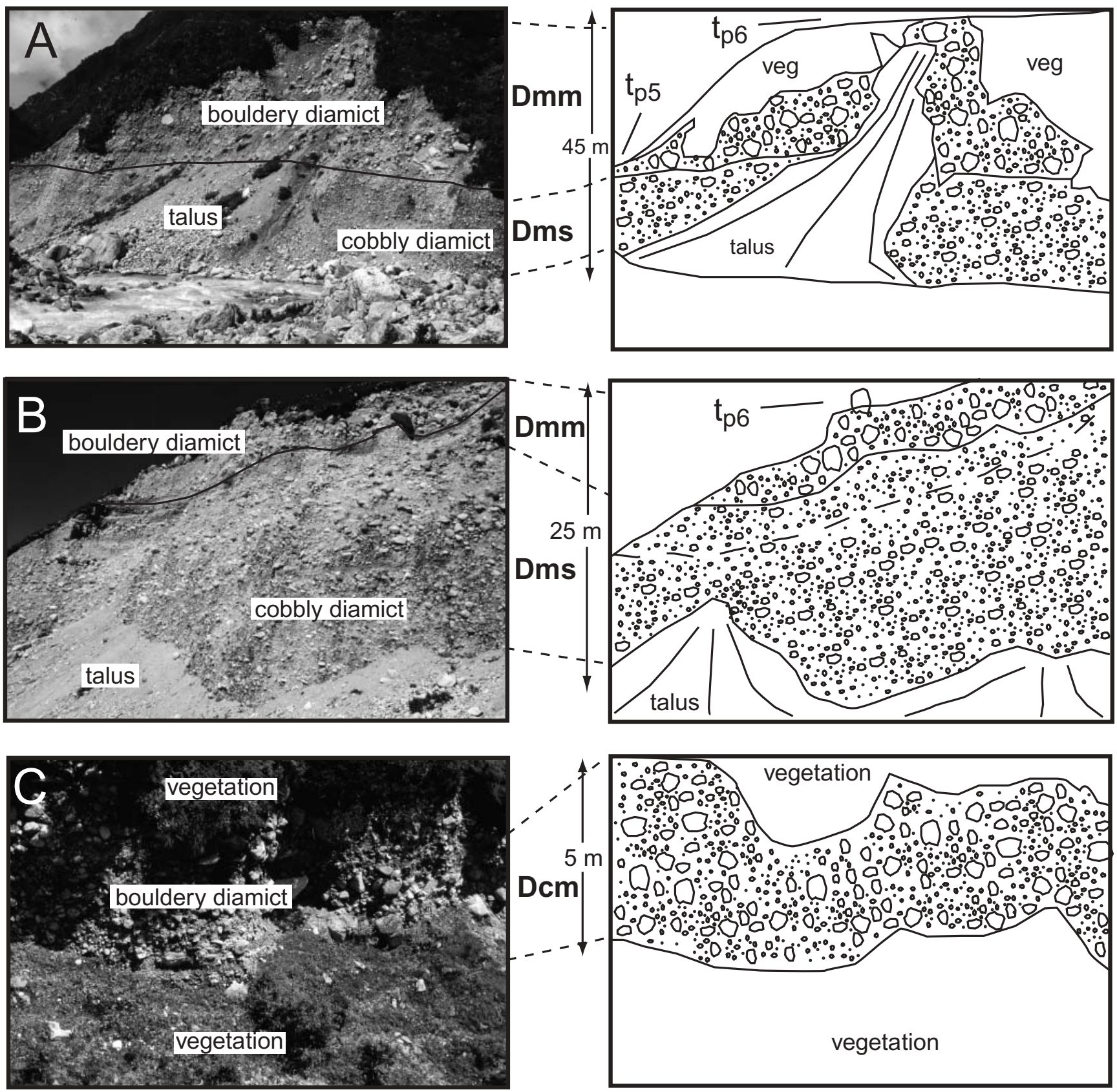

Fig. 4. Typical sedimentary sections from the Pangboche-Yaral study area. (See Fig. 3 for section locations.) (a) Thick section from $\mathrm{p}_{\mathrm{p} 6}$ on the Pangboche side of the valley with a bouldery diamict that overlies a cobbly diamict. (b) Similar section from $t_{p 7}$ below Chhulungche on the Yaral side of the valley. (c) Section from $\mathrm{t}_{\mathrm{p} 6}$, representing a single unit of bouldery diamict. Lithofacies codes after Eyles et al. (1983) as modified by Benn \& Evans (1998).

terraces. Nevertheless, even if dating errors lie between 10 and $20 \%$, CRN dating is still a vast improvement over relative dating techniques, and the only viable option in an environment where carbon dating is not possible because of the poor production and preservation potential of organic material in the harsh, high Himalayan climate. Whenever practical, the entire range of dates calculated from a given surface is stated and considered. Further information on the methods and calculations employed here has been given by Barnard et al. (2001, 2004a, b), Owen et al. (2001, 2002b), Burbank (2002) and Finkel et al. (2003).

The young CRN ages of 'zero' age inheritance samples
( $n=3,0.41 \pm 0.03 \mathrm{ka}$ ) obtained in our study indicate that the Khumbu Himal sediment probably has a short catchment residence time, which implies that erosion rates are high and thus prior exposure of boulders resting on landform surfaces is, on average, not significant. Ages of samples from the flood deposit at Pangboche $\left(\mathrm{t}_{\mathrm{p} 2}: n=2,0.72 \pm 0.08 \mathrm{ka}\right)$ illustrate that the average prior exposure of boulders in the Khumbu Himal is $<1 \mathrm{ka}$. Therefore, the exposure ages measured do not significantly overestimate the true age of the landforms.

CRN dates on the morphostratigraphically equivalent surfaces on either side of the Yaral-Pangboche area are tightly clustered 

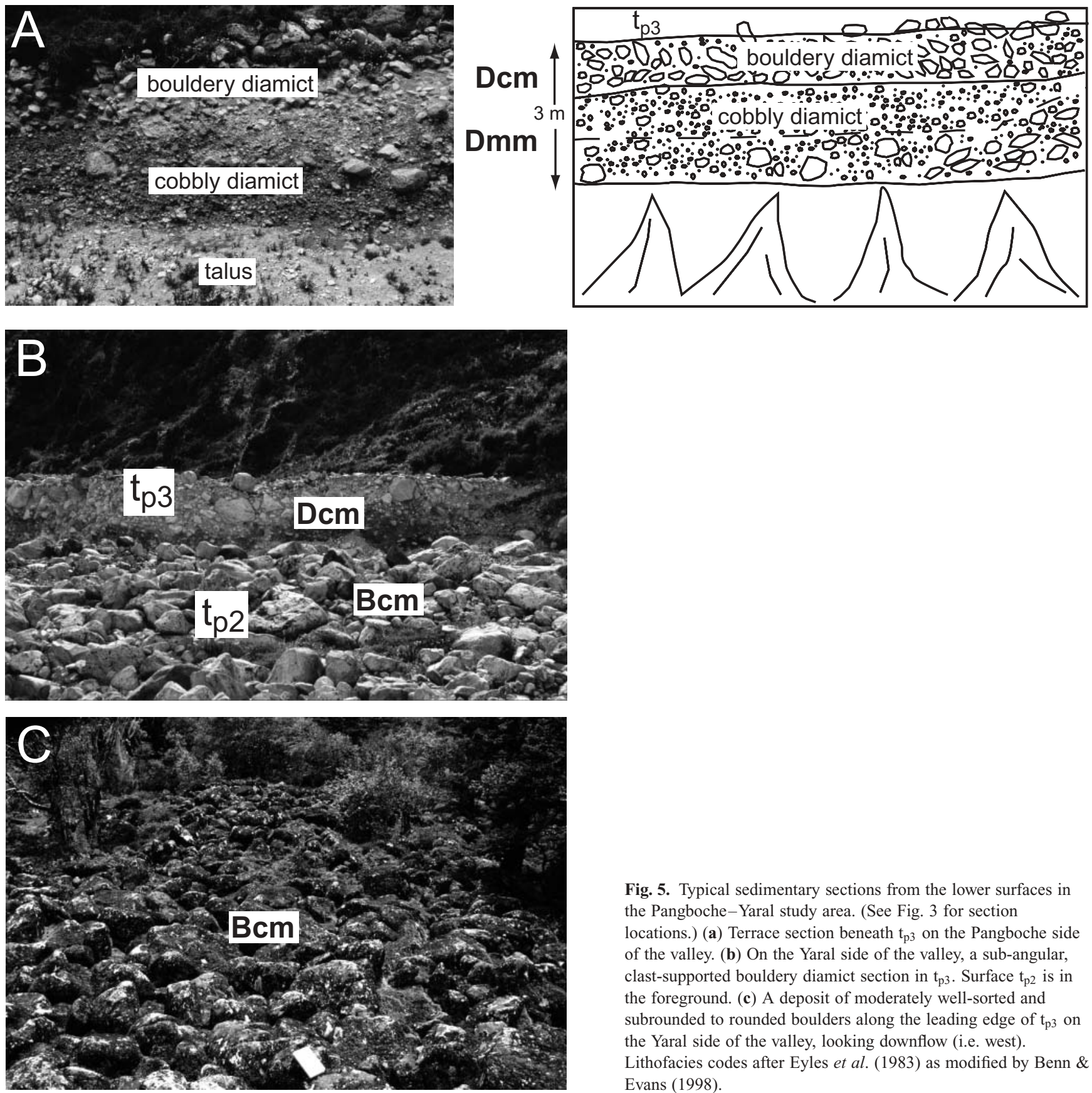

Fig. 5. Typical sedimentary sections from the lower surfaces in the Pangboche-Yaral study area. (See Fig. 3 for section locations.) (a) Terrace section beneath $\mathrm{t}_{\mathrm{p} 3}$ on the Pangboche side of the valley. (b) On the Yaral side of the valley, a sub-angular, clast-supported bouldery diamict section in $t_{p 3}$. Surface $t_{p 2}$ is in the foreground. (c) A deposit of moderately well-sorted and subrounded to rounded boulders along the leading edge of $t_{\mathrm{p} 3}$ on the Yaral side of the valley, looking downflow (i.e. west). Lithofacies codes after Eyles et al. (1983) as modified by Benn \& Evans (1998).

(Table 1, Fig. 9). Samples from $t_{\mathrm{p} 7}$, the highest of the equivalent surfaces, yield an average age of $12.0 \mathrm{ka}(n=7$, ranging from 10.9 to $13.7 \mathrm{ka}$ ). The next lower surface, $\mathrm{t}_{\mathrm{p} 6}$, is dated to $8.1 \mathrm{ka}$ ( $\mathrm{n}=5$, ranging from 7.7 to $8.2 \mathrm{ka}$, rejecting E110). Other prominent surfaces formed at $1.5 \mathrm{ka}\left(\mathrm{t}_{\mathrm{p} 3}\right)$ and from the $\mathrm{AD} 1977$ glacial-lake outburst flood ( $\mathrm{t}_{\mathrm{p} 2}$ : Ives 1986; Zimmermann et al. 1986; Cenderelli \& Wohl 2001; Fig. 3). A small set of CRN dates on the high fans in the Yaral-Pangboche area suggest episodes of fan sedimentation at c. $58 \mathrm{ka}\left(\mathrm{f}_{\mathrm{p} 3}\right), 17 \mathrm{ka}\left(\mathrm{f}_{\mathrm{p} 2}\right)$ and $14 \mathrm{ka}\left(\mathrm{f}_{\mathrm{p} 1}\right)$.

Three surfaces were dated at Orsho (Table 1, Fig. 9). The most prominent terrace, $\mathrm{t}_{06}$, has a weighted average age of $11.0 \mathrm{ka}$ ( $n=3$, ranging from 9.7 to $14.3 \mathrm{ka}$ ). The next lower prominent terrace, $\mathrm{t}_{04}$, dates to $4.8 \mathrm{ka}$ ( $n=6$, ranging from 4.1 to $5.2 \mathrm{ka}$, rejecting E15, E17 and E25). The rejected (not included in the weighted mean calculation) boulders (E15, age $12.1 \pm 0.3 \mathrm{ka}$; E17, age $35.2 \pm 1.5 \mathrm{ka}$; E25, age $10.1 \pm 0.3 \mathrm{ka}$ ) are considered to be pre-exposed, because their ages are significantly older than the tightly clustered set of three CRN ages that seem to define the age of this terrace and they are equivalent to or exceed the CRN ages from the higher and older surface $\left(t_{06}\right)$. The next lower terrace surface in the succession, $\mathrm{t}_{\mathrm{o} 3}$, is dated to $c .4 .4 \mathrm{ka}(n=3$, ranging from 4.0 to $4.7 \mathrm{ka}$ ).

CRN surface exposure dates on boulders on the Dingboche terrace $\left(t_{\mathrm{d} 3}\right)$ provide dates of 12.2 and $14.7 \mathrm{ka}$ (rejecting E26, age $6.2 \pm 0.2 \mathrm{ka}$, morphostratigraphically similar surfaces at Pang- 


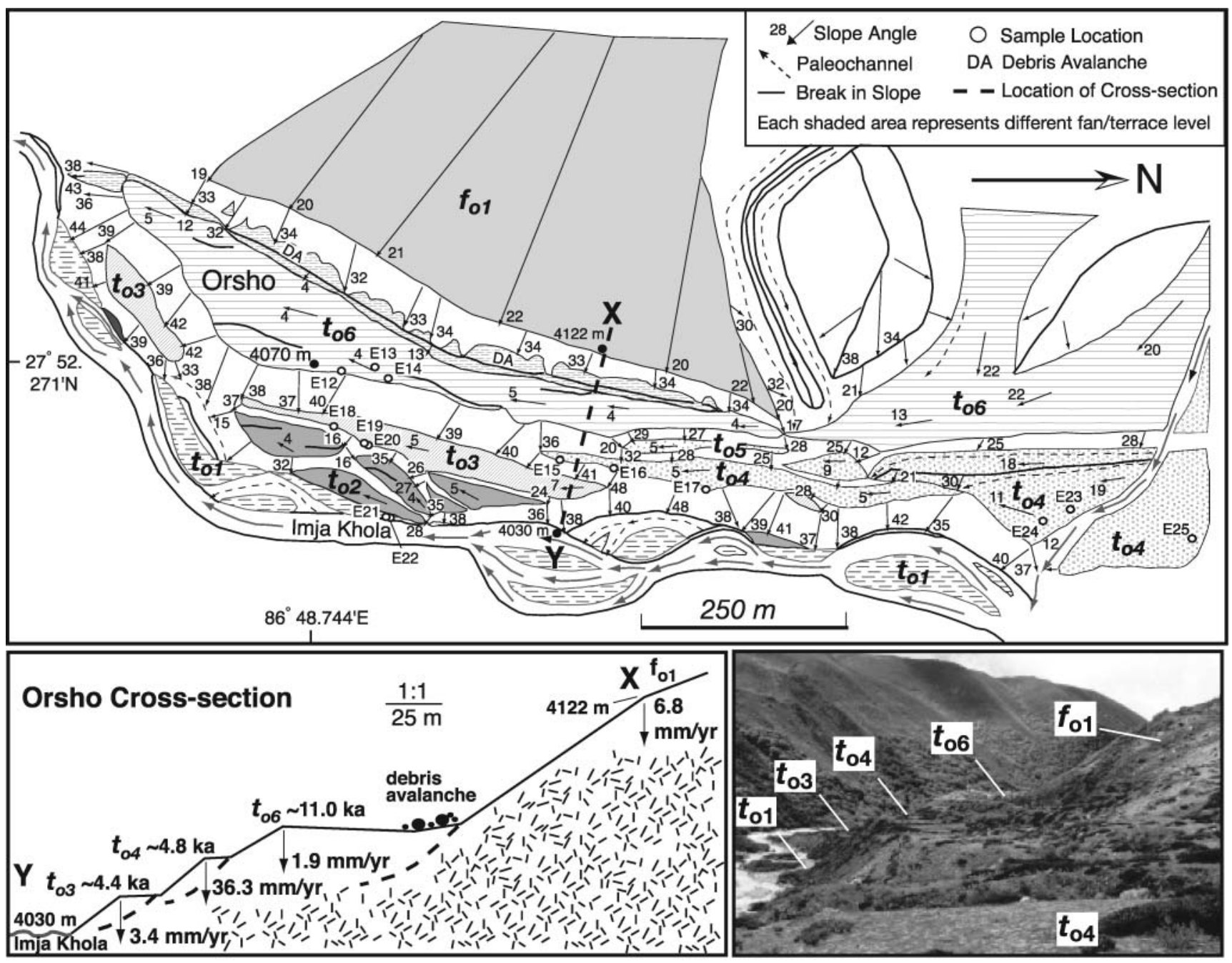

Fig. 6. Geomorphological map of the Orsho study area with a valley profile, landform dates, and cross-section. The photograph shows a view looking downvalley normal to the valley profile. Mapped at a scale of 1:5000. No vertical exaggeration for the cross-section.

boche and Orsho date to $>10 \mathrm{ka}$, truncated moraine dates to $16 \mathrm{ka}$ ), which suggest that fan sedimentation ceased by $c$. $12.2 \mathrm{ka}$. A Late-glacial age for this fan is further supported by the $c .16 \mathrm{ka}$ ages on moraines that are overlain by this terrace (Finkel et al. 2003; Fig. 7). Furthermore, this terrace is morphostratigraphically equivalent to the prominent surfaces at Pangboche ( $\mathrm{t}_{\mathrm{p} 6}$; see Fig. 3$)$ and Orsho ( $\mathrm{t}_{\mathrm{o} 6}$; see Fig. 6) that are dated to $c .12 \mathrm{ka}$ and $c .11 \mathrm{ka}$, respectively. The morphostratigraphic equivalence of each fan or terrace succession was determined by the slope and elevation of each surface, sedimentology, and the surface morphology.

Ages on the two lower Dingboche surfaces, $t_{d 2}$ and $t_{d 1}$, range between 4 and $5 \mathrm{ka}$. The higher terrace, $\mathrm{t}_{\mathrm{d} 2}$, is dated to $c .4 .9 \mathrm{ka}$ $(n=2$, rejecting E65 and E66, both with ages $3.0 \pm 0.1 \mathrm{ka}$, younger than the terrace below it). Fan $\mathrm{t}_{\mathrm{d} 1}$ dates to $c .4 .1 \mathrm{ka}$ ( $\mathrm{n}=2$, rejecting E68, age $2.81 \pm 0.2 \mathrm{ka}$ ). The ages of the lower Dingboche surfaces are approximately equivalent to $t_{04}$ and $t_{03}$ at Orsho, which are dated to c. 4.8 and $4.4 \mathrm{ka}$, respectively. Alternatively, these two lower fans at Dingboche could date to $c$. $3.0 \mathrm{ka}$ and c. $2.8 \mathrm{ka}$, respectively, if the other samples were rejected instead, but this seems unlikely given the similar succession of surfaces at nearby Orsho.
The Imja Khola valley narrows into a deep gorge immediately downvalley of the Pangboche area (Fig. 10). Four strath terraces cut into the sides of this gorge and have ages of $3.7 \pm 0.1 \mathrm{ka}$, $6.6 \pm 0.3 \mathrm{ka}, 12.6 \pm 0.3 \mathrm{ka}$ and $16.2 \pm 0.4 \mathrm{ka}$ (Table 1). These ages indicate incision rates of $3.4-4.3 \mathrm{~mm} \mathrm{a}^{-1}$, with an average of $3.9 \mathrm{~mm} \mathrm{a}^{-1}$ (Table 2). Given that the valley is narrow at this point, it is unlikely that these strath terraces were sites of prolonged sediment storage during the Late Pleistocene (see Pratt et al. 2002).

\section{Discussion}

Stratigraphic analysis of the Late Pleistocene and Holocene fans and terraces in the Khumbu Himal indicates that the sediments have characteristics of both hyperconcentrated flows and debris flows (Fig. 11). Hyperconcentrated flows are commonly associated with floods containing high sediment loads whereas debris flows are associated with regolith slopes or sedimentary deposits that have become soaked with water during rainstorms or snow melts.

The bouldery diamicts that are prevalent in Khumbu fans and terraces have characteristics common to debris flows (e.g. 

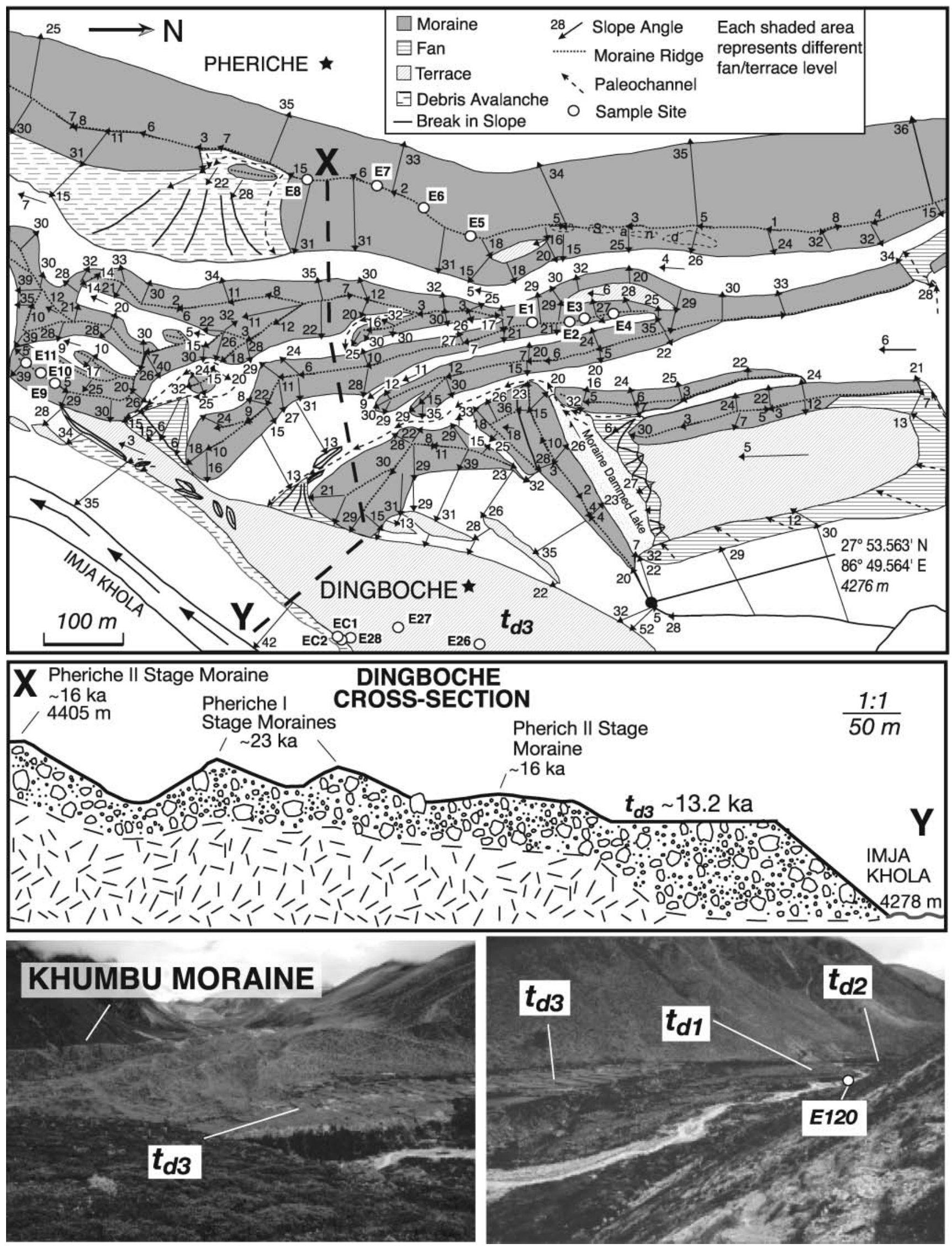

\section{(1)}

Pherich II Stage

$\frac{1: 1}{50 m}$

Moraine

$\sim 16 \mathrm{ka}$ 

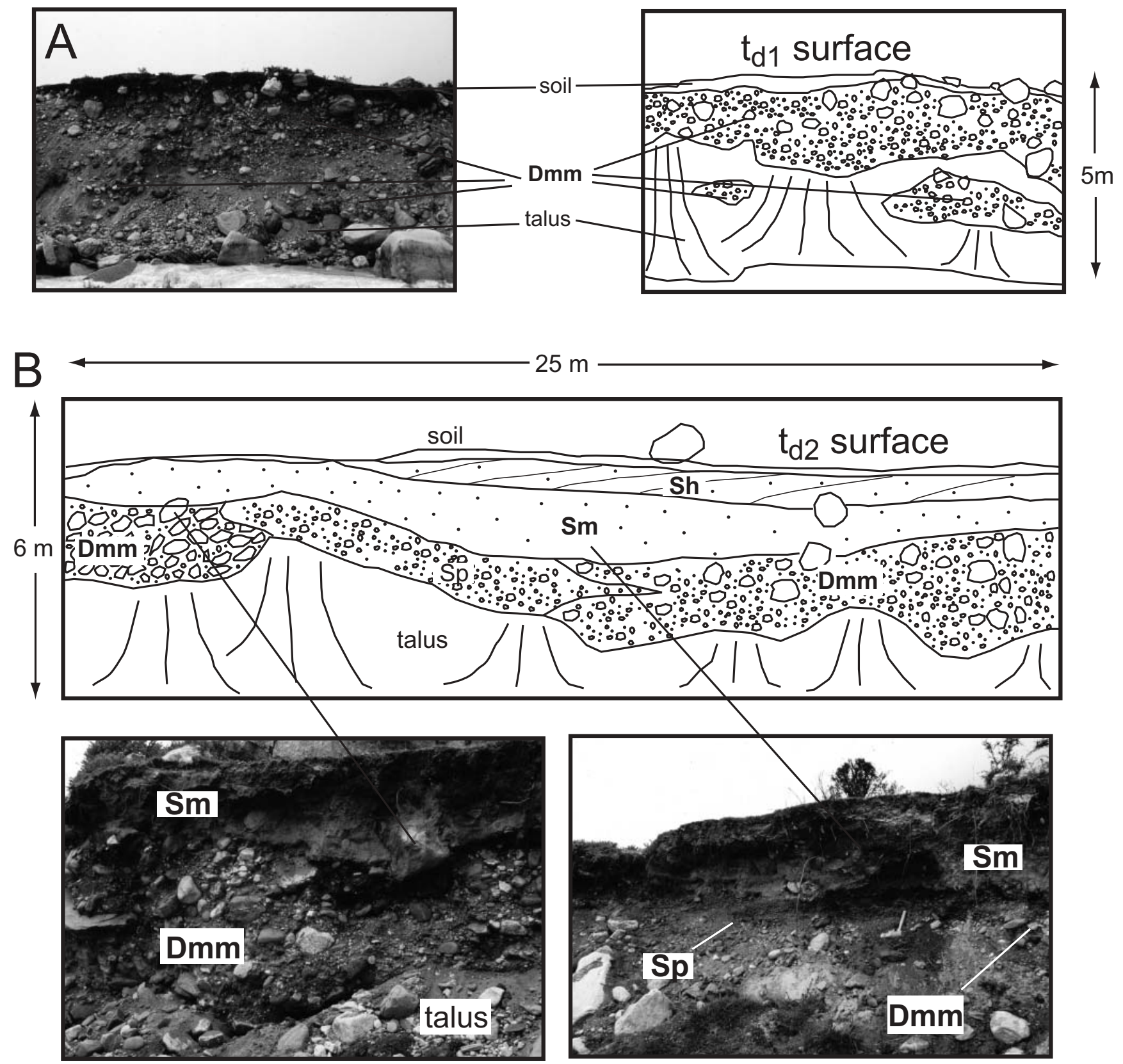

Fig. 8. Sections in the Dingboche study area. (a) Diamict in $t_{d 1}$ section is massive with subrounded cobbles, borderline matrix-supported by sandy pebbles with occasional boulders concentrated near surface, pockets of extensive imbrication in cobbles and pebbles, $4 \mathrm{~m}$ diameter boulders on surface. (b) Section in $\mathrm{t}_{\mathrm{d} 2}$. Lithofacies codes after Eyles et al. (1983) as modified by Benn \& Evans (1998).

isotropic macroclast fabrics, boulder-dominated, massive, ungraded) that originate from glacial deposits (Beverage \& Culbertson 1964; Costa 1988; Ballantyne 1995, 2002, 2003; Zielinski \& van Loon 1996; Barnard et al. 2004a). Zielinski \& van Loon (1996) identified similar deposits in their study of fans derived from end moraines in Poland. Using the classification of Schultz (1984), the bouldery diamicts described in this study would be termed clast-rich debris flows, a sediment gravity flow transitional between debris flow and granular flow. Sohn et al. (1999) described clast-supported debris flows on alluvial fan deposits in the Yongdong Basin, Korea. By comparison with their study, the bouldery diamicts studied in the Khumbu Himal would fall into the upper end of the debris flow category, more similar to hyperconcentrated flows. The moderate banding, crude stratification, downvalley clast orientation and matrix-supported character of the cobbly diamicts suggest that the sediment was deposited by hyperconcentrated flows (Coussat \& Meunier 1996). However, the lack of clast support, sedimentary structures and strong banding indicate that these deposits also contain features characteristic of debris flows. The moderate banding suggests that the sediments were slightly washed, and low mud content and cobble-size clast capacity indicate that fluvial flow conditions (i.e. turbulent flow) were more dominant than debris flow (i.e. laminar flow) conditions (Costa 1988). 
Table 1. ${ }^{10}$ Be ages of fan, terrace and inheritance samples in the study area

\begin{tabular}{|c|c|c|c|c|c|c|c|c|}
\hline $\begin{array}{l}\text { Sample } \\
\text { number }\end{array}$ & Landform number & $\begin{array}{c}\text { Latitude } \\
\left( \pm 0.01^{\circ}\right) \\
\left({ }^{\circ} \mathrm{N}\right)\end{array}$ & $\begin{array}{l}\text { Longitude } \\
\left( \pm 0.01^{\circ}\right) \\
\left({ }^{\circ} \mathrm{E}\right)\end{array}$ & $\begin{array}{l}\text { Altitude } \\
\text { (m) }\end{array}$ & $\begin{array}{l}\text { Shielding } \\
\text { factor* }\end{array}$ & $\begin{array}{c}{ }^{10} \mathrm{Be}^{\dagger} \\
\left(10^{6} \text { atoms } / \mathrm{g}\right)\end{array}$ & $\begin{array}{l}\text { Exposure age, } \\
{ }^{10} \mathrm{Be}^{\dagger}(\mathrm{ka})\end{array}$ & $\begin{array}{l}\text { Exposure age with } \\
\text { geomagnetic } \\
\text { correlation* }(\mathrm{ka})\end{array}$ \\
\hline \multicolumn{9}{|l|}{ Orsho } \\
\hline E12 & Terrace; $\mathrm{t}_{\mathrm{o} 6}$ & 27.87 & 86.81 & 3971 & 0.98 & $0.734 \pm 0.018$ & $13.41 \pm 0.32$ & $14.26 \pm 0.34$ \\
\hline E13 & Terrace; $t_{06}$ & 27.87 & 86.81 & 3998 & 0.98 & $0.515 \pm 0.013$ & $9.27 \pm 0.23$ & $9.74 \pm 0.24$ \\
\hline E14 & Terrace; $\mathrm{t}_{\mathrm{o} 6}$ & 27.87 & 86.81 & 3998 & 0.98 & $0.537 \pm 0.019$ & $9.67 \pm 0.34$ & $10.15 \pm 0.36$ \\
\hline E15 & Terrace; $t_{04}$ & 27.87 & 86.81 & 4009 & 0.98 & $0.637 \pm 0.016$ & $11.43 \pm 0.28$ & $12.10 \pm 0.30$ \\
\hline E16 & Terrace; $t_{04}$ & 27.87 & 86.81 & 4126 & 0.98 & $0.257 \pm 0.007$ & $4.34 \pm 0.13$ & $5.02 \pm 0.15$ \\
\hline E17 & Terrace; $t_{04}$ & 27.87 & 86.81 & 4159 & 0.98 & $2.087 \pm 0.088$ & $34.95 \pm 1.47$ & $35.21 \pm 1.48$ \\
\hline E18 & Terrace; $t_{03}$ & 27.87 & 86.81 & 3927 & 0.98 & $0.219 \pm 0.007$ & $4.09 \pm 0.13$ & $4.74 \pm 0.15$ \\
\hline E19 & Terrace; $t_{03}$ & 27.87 & 86.81 & 3927 & 0.98 & $0.180 \pm 0.007$ & $3.36 \pm 0.13$ & $3.97 \pm 0.15$ \\
\hline E20 & Terrace; $t_{03}$ & 27.87 & 86.81 & 3927 & 0.98 & $0.204 \pm 0.008$ & $3.81 \pm 0.15$ & $4.45 \pm 0.17$ \\
\hline E21 & Inheritance & 27.87 & 86.81 & 3828 & 0.99 & $0.056 \pm 0.004$ & $1.09 \pm 0.08$ & $1.13 \pm 0.09$ \\
\hline E22 & Inheritance & 27.87 & 86.81 & 4123 & 0.99 & $0.016 \pm 0.003$ & $0.27 \pm 0.05$ & $0.24 \pm 0.04$ \\
\hline E23 & Terrace; $t_{04}$ & 27.88 & 86.81 & 4140 & 0.98 & $0.207 \pm 0.007$ & $3.47 \pm 0.12$ & $4.11 \pm 0.14$ \\
\hline E24 & Terrace; $t_{04}$ & 27.88 & 86.81 & 4140 & 0.98 & $0.268 \pm 0.007$ & $4.49 \pm 0.12$ & $5.17 \pm 0.14$ \\
\hline E25 & Terrace; $\mathrm{t}_{04}$ & 27.88 & 86.81 & 4105 & 0.98 & $0.560 \pm 0.014$ & $9.56 \pm 0.24$ & $10.05 \pm 0.25$ \\
\hline \multicolumn{9}{|l|}{ Dingboche } \\
\hline E26 & Terrace; $t_{03}$ & 27.87 & 86.83 & 4482 & 0.99 & $0.393 \pm 0.010$ & $5.54 \pm 0.14$ & $6.16 \pm 0.16$ \\
\hline E27 & Terrace; $t_{03}$ & 27.87 & 86.83 & 4482 & 0.99 & $0.972 \pm 0.024$ & $13.72 \pm 0.34$ & $14.63 \pm 0.36$ \\
\hline E28 & Terrace; $t_{03}$ & 27.87 & 86.81 & 4482 & 0.99 & $0.814 \pm 0.020$ & $11.48 \pm 0.29$ & $12.19 \pm 0.30$ \\
\hline E64 & Terrace; $t_{\mathrm{d} 2}$ & 27.90 & 86.84 & 4497 & 0.97 & $0.253 \pm 0.008$ & $3.59 \pm 0.12$ & $4.26 \pm 0.14$ \\
\hline E65 & Terrace; $t_{\mathrm{d} 2}$ & 27.90 & 86.84 & 4475 & 0.97 & $0.182 \pm 0.006$ & $2.61 \pm 0.08$ & $3.02 \pm 0.09$ \\
\hline E66 & Terrace; $t_{\mathrm{d} 2}$ & 27.90 & 86.84 & 4425 & 0.97 & $0.177 \pm 0.006$ & $2.60 \pm 0.09$ & $3.00 \pm 0.11$ \\
\hline E67 & Terrace; $t_{\mathrm{d} 2}$ & 27.90 & 86.84 & 4413 & 0.97 & $0.348 \pm 0.010$ & $5.14 \pm 0.15$ & $5.80 \pm 0.17$ \\
\hline E68 & Terrace; $t_{\mathrm{d} 1}$ & 27.90 & 86.84 & 4317 & 0.97 & $0.159 \pm 0.009$ & $2.46 \pm 0.13$ & $2.81 \pm 0.15$ \\
\hline E69 & Terrace; $t_{d 1}$ & 27.90 & 86.84 & 4278 & 0.97 & $0.215 \pm 0.006$ & $3.39 \pm 0.10$ & $4.03 \pm 0.12$ \\
\hline E70 & Terrace; $t_{\mathrm{d} 1}$ & 27.90 & 86.84 & 4270 & 0.97 & $0.226 \pm 0.006$ & $3.58 \pm 0.10$ & $4.23 \pm 0.12$ \\
\hline \multicolumn{9}{|l|}{ Tsadorje } \\
\hline E90 & Strath & 27.85 & 86.78 & 3781 & 0.92 & $0.146 \pm 0.005$ & $3.14 \pm 0.12$ & $3.68 \pm 0.14$ \\
\hline E91 & Strath & 27.85 & 86.78 & 3792 & 0.94 & $0.291 \pm 0.015$ & $6.07 \pm 0.31$ & $6.60 \pm 0.34$ \\
\hline E92 & Strath & 27.85 & 86.78 & 3870 & 0.96 & $0.605 \pm 0.016$ & $11.86 \pm 0.31$ & $12.57 \pm 0.32$ \\
\hline \multirow{2}{*}{\multicolumn{9}{|c|}{$0.180 \pm 0.020$}} \\
\hline & & & & & & & & \\
\hline E95 & Terrace; $t_{p 7}$ & 27.86 & 86.80 & 3952 & 0.98 & $0.673 \pm 0.017$ & $12.39 \pm 0.32$ & $13.15 \pm 0.34$ \\
\hline E96 & Terrace; $t_{\mathrm{p} 7}$ & 27.85 & 86.80 & 4122 & 0.98 & $0.665 \pm 0.017$ & $11.24 \pm 0.29$ & $11.91 \pm 0.30$ \\
\hline E97 & Terrace; $t_{\mathrm{p} 7}$ & 27.85 & 86.80 & 4207 & 0.98 & $0.672 \pm 0.017$ & $10.89 \pm 0.28$ & $11.52 \pm 0.30$ \\
\hline E98 & Terrace; $\mathrm{t}_{\mathrm{p} 7}$ & 27.85 & 86.79 & 3969 & 0.98 & $0.654 \pm 0.017$ & $11.99 \pm 0.31$ & $12.71 \pm 0.33$ \\
\hline E99 & Terrace; $\mathrm{t}_{\mathrm{p} 6}$ & 27.85 & 86.80 & 4114 & 0.98 & $0.434 \pm 0.011$ & $7.37 \pm 0.19$ & $7.80 \pm 0.21$ \\
\hline E100 & Terrace; $\mathrm{t}_{\mathrm{p} 6}$ & 27.85 & 86.80 & 4058 & 0.98 & $0.414 \pm 0.011$ & $7.23 \pm 0.19$ & $7.67 \pm 0.20$ \\
\hline E101 & Terrace; $\mathrm{t}_{\mathrm{p} 6}$ & 27.85 & 86.80 & 4058 & 0.98 & $0.423 \pm 0.013$ & $7.40 \pm 0.22$ & $7.83 \pm 0.23$ \\
\hline E102 & Terrace; $t_{\mathrm{p} 3}$ & 27.85 & 86.80 & 3963 & 0.98 & $0.088 \pm 0.005$ & $1.62 \pm 0.10$ & $1.75 \pm 0.11$ \\
\hline E103 & Terrace; $t_{\mathrm{p} 3}$ & 27.85 & 86.79 & 3963 & 0.98 & $0.090 \pm 0.005$ & $1.64 \pm 0.10$ & $1.78 \pm 0.11$ \\
\hline E104 & Terrace; $t_{\mathrm{p} 3}$ & 27.85 & 86.79 & 3963 & 0.98 & $0.067 \pm 0.004$ & $1.24 \pm 0.07$ & $1.30 \pm 0.08$ \\
\hline E105 & Terrace; $\mathrm{t}_{\mathrm{p} 2}$ & 27.85 & 86.79 & 3903 & 0.98 & $0.009 \pm 0.000$ & $0.16 \pm 0.00$ & $0.15 \pm 0.00$ \\
\hline E106 & Terrace; $\mathrm{t}_{\mathrm{p} 2}$ & 27.85 & 86.79 & 3815 & 0.97 & $0.062 \pm 0.004$ & $1.23 \pm 0.08$ & $1.29 \pm 0.08$ \\
\hline E107 & Fan; $f_{p 1}$ & 27.85 & 86.80 & 4059 & 0.98 & $0.729 \pm 0.021$ & $12.78 \pm 0.37$ & $13.58 \pm 0.40$ \\
\hline E108 & Fan; $f_{p 1}$ & 27.85 & 86.80 & 4033 & 0.98 & $0.479 \pm 0.045$ & $8.50 \pm 0.80$ & $8.96 \pm 0.84$ \\
\hline \multicolumn{9}{|l|}{ Pangboche } \\
\hline E109 & Terrace; $\mathrm{t}_{\mathrm{p} 6}$ & 27.86 & 86.79 & 3985 & 0.98 & $0.496 \pm 0.023$ & $8.97 \pm 0.42$ & $9.45 \pm 0.44$ \\
\hline E110 & Terrace; $\mathrm{t}_{\mathrm{p} 6}$ & 27.85 & 86.79 & 3970 & 0.98 & $1.119 \pm 0.034$ & $20.55 \pm 0.62$ & $21.66 \pm 0.66$ \\
\hline E111 & Terrace; $t_{\mathrm{p} 6}$ & 27.85 & 86.79 & 3979 & 0.98 & $0.429 \pm 0.013$ & $7.81 \pm 0.24$ & $8.22 \pm 0.25$ \\
\hline E112 & Terrace; $\mathrm{t}_{\mathrm{p} 7}$ & 27.85 & 86.79 & 3960 & 0.98 & $0.700 \pm 0.017$ & $12.86 \pm 0.32$ & $13.66 \pm 0.34$ \\
\hline E113 & Terrace; $t_{\mathrm{p} 7}$ & 27.85 & 86.79 & 4021 & 0.98 & $0.602 \pm 0.018$ & $10.72 \pm 0.32$ & $11.32 \pm 0.34$ \\
\hline E114 & Terrace; $t_{p 7}$ & 27.86 & 86.79 & 4061 & 0.98 & $0.592 \pm 0.015$ & $10.33 \pm 0.27$ & $10.89 \pm 0.28$ \\
\hline E115 & Fan; $f_{p 2}$ & 27.86 & 86.79 & 3956 & 0.98 & $0.859 \pm 0.024$ & $15.86 \pm 0.43$ & $16.82 \pm 0.46$ \\
\hline E116 & Fan; $f_{p 3}$ & 27.86 & 86.79 & 4028 & 0.98 & $7.282 \pm 0.169$ & $132.57 \pm 3.08$ & $127.32 \pm 2.96$ \\
\hline E117 & Fan; $\mathrm{f}_{\mathrm{p} 3}$ & 27.86 & 86.79 & 3941 & 0.98 & $2.739 \pm 0.054$ & $51.19 \pm 1.00$ & $49.98 \pm 0.98$ \\
\hline E118 & Terrace; $t_{\mathrm{p} 4}$ & 27.85 & 86.79 & 3818 & 0.98 & $0.261 \pm 0.009$ & $5.17 \pm 0.17$ & $5.79 \pm 0.19$ \\
\hline E119 & Terrace; $\mathrm{t}_{\mathrm{p} 4}$ & 27.85 & 86.79 & 3875 & 0.98 & $0.518 \pm 0.000$ & $9.97 \pm 0.00$ & $10.49 \pm 0.00$ \\
\hline \multicolumn{9}{|l|}{ Dingboche } \\
\hline E120 & Inheritance & 27.89 & 86.84 & 4286 & 0.99 & $0.034 \pm 0.004$ & $0.52 \pm 0.06$ & $0.47 \pm 0.06$ \\
\hline
\end{tabular}

*The topographic shielding factor was determined using the methods of Nishiizumi et al. (1989).

†ncertainty includes only uncertainty in accelerator mass spectrometry.

${ }^{\ddagger}$ Corrected for time-varying geomagnetic field as described in text. The uncertainty is carried over from that in the exposure age. No additional uncertainty was assigned arising from correction for geomagnetic field change. These ages were calculated with a sea-level high-latitude production of ${ }^{10} \mathrm{Be}$ of 5.16 atoms/g of quartz/year grain using the scaling factors of Lal (1991) as modified by Stone (2000). 


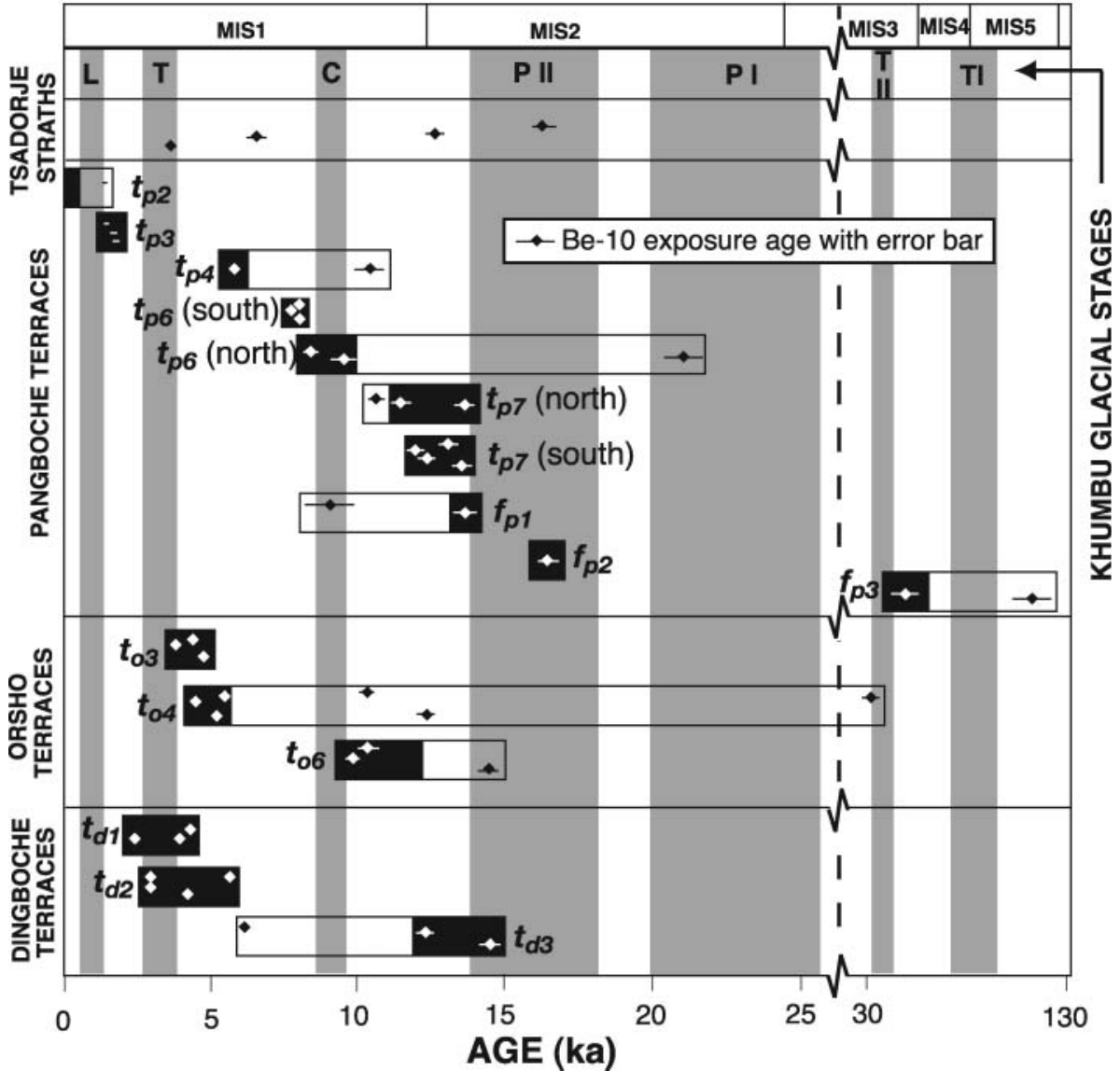

Fig. 9. The correlation of fan or terrace ages for each of the Khumbu Himal study areas compared with the strath terraces ages and the glacial stages of Finkel et al. (2003). The areas shaded in dark grey is the inferred age for each fan. Glacial stages: L, Lobuche; T, Thuklha; C, Chhukhung; PII, Pheriche II; PI, Pheriche I; TII, Thyangboche II; TI, Thyangboche I.
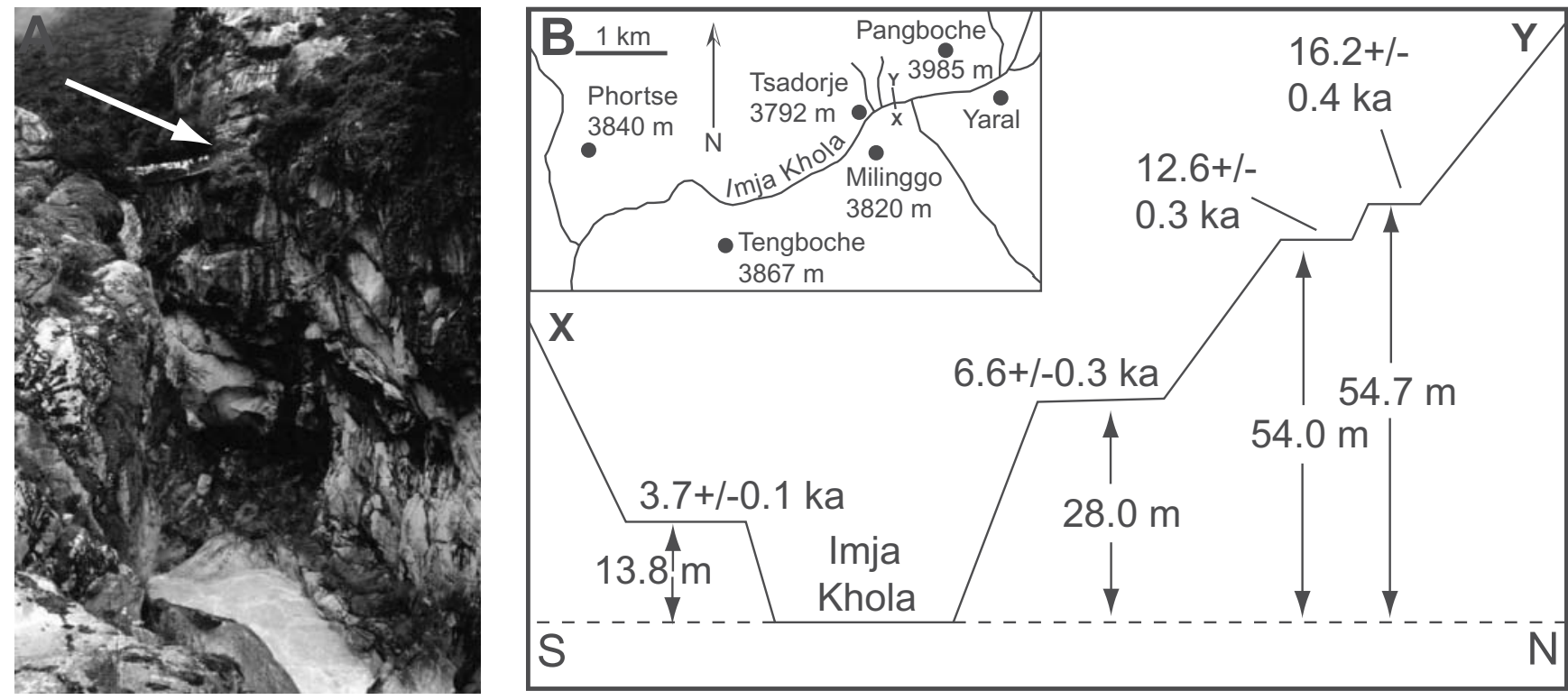

Fig. 10. (a) The $28 \mathrm{~m}$ deep gorge cut by the Imja Khola beneath the second lowest strath terrace. White arrow points to location of sample E91). (b) Schematic representation of strath terrace sampling locations and calculated CRN ages in the Imja Khola Valley at Tsadorje.

These observations suggest that the Khumbu fans and terraces comprise a combination of debris-flow and hyperconcentrated flow deposits. However, it is difficult to assign an unequivocal causal mechanism to individual units, particularly because of the continuum of processes and forms that characterize hyperconcentrated and debris flows and their products (Fig. 11).

The CRN dating suggests that for all but one (at $12 \mathrm{ka}$ ) of the major cycles of strath terrace, terrace and fan formation, which 
Table 2. Incision rates calculated from the CRN exposure ages of strath terraces at Tsadorje

\begin{tabular}{lcccc}
\hline $\begin{array}{l}\text { Landform } \\
\text { number }\end{array}$ & $\begin{array}{c}\text { Altitude } \\
(\mathrm{m})\end{array}$ & $\begin{array}{c}{ }^{10} \text { Be exposure } \\
\text { age }(\mathrm{ka})\end{array}$ & $\begin{array}{c}\text { Height } \\
(\mathrm{m})\end{array}$ & $\begin{array}{c}\text { Rate } \\
\left(\mathrm{mm} \mathrm{a}^{-1}\right)\end{array}$ \\
\hline E90 & 3781 & $3.7 \pm 0.1$ & 13.8 & 3.8 \\
E91 & 3792 & $6.6 \pm 0.3$ & 28.0 & 4.2 \\
E92 & 3870 & $12.6 \pm 0.3$ & 54.0 & 4.3 \\
E93 & 3880 & $16.2 \pm 0.4$ & 54.7 & 3.4 \\
& & \multicolumn{3}{c}{ Average $=3.9$} \\
\hline
\end{tabular}
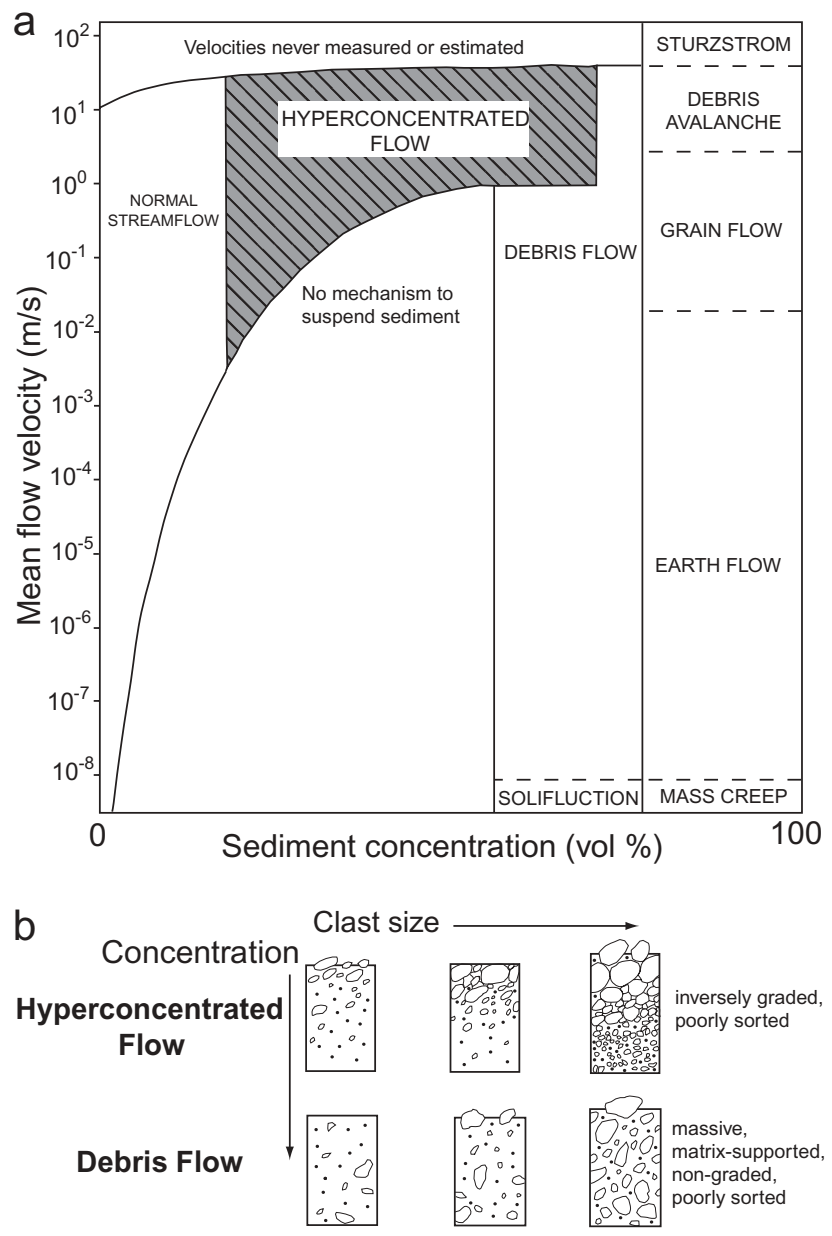

Fig. 11. A comparison of hyperconcentrated flows and debris flows. (a) A rheological classification of subaerial sediment-water flows. The striped, shaded region represents the area of transition between true Newtonian fluid type flow behaviour (stream flow) and non-Newtonian or plastic flow (debris flow) (modified from Pierson \& Costa (1987) and Svendsen et al. (2003)). (b) Examples of the fabrics of typical coarse debris flows and hyperconcentrated flows. These are similar to those described from fans or terraces in the Khumbu Himal (modified from Maizels 1993).

occurred at c. $16 \mathrm{ka}, 12 \mathrm{ka}, 8 \mathrm{ka}, 4 \mathrm{ka}$, and $1.5 \mathrm{ka}$ (Fig. 12), there is a tentative correlation with each glacial stage (Fig. 9, Table 3). Therefore it is likely that the formation of these surfaces can be linked with the termination of the glacial stages as established by Finkel et al. (2003) when glacial and associated sediments are

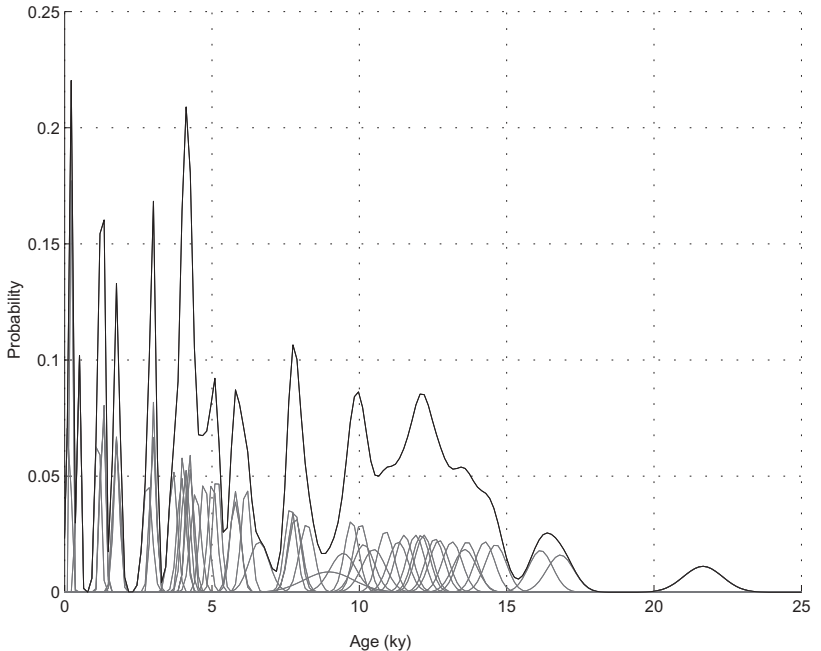

Fig. 12. Age distribution probability density function plot (also known as a 'camel' plot) for the landforms dated in this study.

eroded and resedimented by paraglacial processes such as glacial-lake outburst floods and landsliding. Hence it follows that terrace and fan formation is linked with regional and global climatostratigraphic stages.

CRN dating of the fan and terraces in the Khumbu Himal supports the hypothesis that major sedimentation events follow glacier advances within a few thousand years. The unbedded, thick diamict deposits, representing debris flow and hyperconcentrated flow deposits, perhaps indicate that glacial retreat was rapid, resulting in rapid glacial-lake build-up and eventually catastrophic flooding from subsequent moraine dam breaching, flooding that affected large areas of the Khumbu Himal. CRN dating and sedimentological evidence linking deglaciation with large-scale fan or terrace sedimentation has been suggested by work in the Lahul and in Garhwal Himalaya (Owen et al. 2001; Barnard et al. 2004a).

At Pangboche, $\mathrm{f}_{\mathrm{p} 2}$ formed at c. $16.8 \mathrm{ka}$, approximately coincident with the beginning of the Pheriche II Stage $(16.0 \mathrm{ka})$, or possibly the end of the Pheriche I (Finkel et al. 2003). Also at Pangboche, five of six CRN samples indicate that $t_{\mathrm{p} 6}$ was deposited (c. $8.1 \mathrm{ka}$ ) broadly with the termination of the Chhukhung Stage (c. $9.2 \mathrm{ka}$ ) and its sediments display typical paraglacial features (e.g. striated clasts). The existence of several terraces dated at 4-5 ka, at both Dingboche and Orsho, suggests that the mid-Holocene was a time of heightened sediment flux. Poor dating control on a surface at Pangboche ( $\mathrm{t}_{\mathrm{p} 4}$, two samples, dated at 5.8 and $10.5 \mathrm{ka}$ ), however, prevents this fan from being correlated with mid-Holocene landforms that formed upvalley. Nevertheless, glacial fluctuations during the Thuklha Stage (c. 3.6 ka: Finkel et al. 2003) probably resulted in significant fluxes of sediment during the mid-Holocene, possibly controlling the formation of the two sets of mid-Holocene fans at Dingboche and Orsho that date between c. 4.1 and $4.9 \mathrm{ka}$ (Table 3). The geomorphological mapping and sedimentological analysis that suggest rapid incision and large-scale resedimentation events during the mid-Holocene support this view. Terrace $t_{\mathrm{p} 3}$ (c. $1.5 \mathrm{ka})$ may relate to the Lobuche Stage (c. $1 \mathrm{ka}$ ) (Finkel et al. 2003). Modern flood deposits at Pangboche $\left(t_{\mathrm{p} 2}\right)$ may be the result of Little Ice Age retreat.

The prominent set of fans and terraces $\left(t_{p 7}, t_{06}, t_{d 3}\right)$ that are 


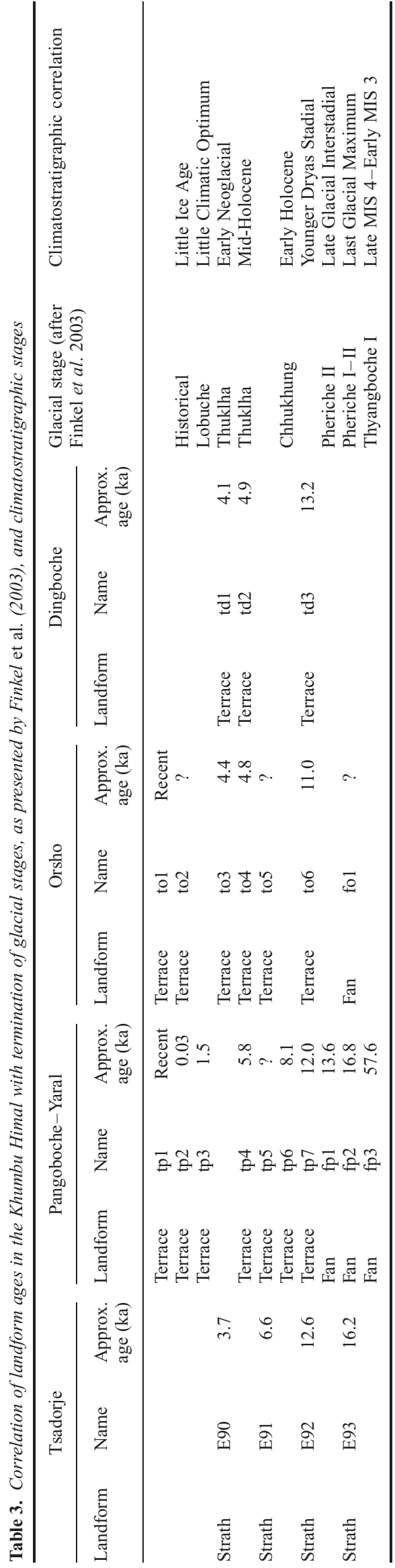

dated at c. $12 \mathrm{ka}$ in each of the three major study areas may not be glaciogenic in origin because there is no evidence for $c .12 \mathrm{ka}$ old source moraines for the fan sediments. The fan sedimentology and stratigraphy are indicative of the same debris and hyperconcentrated flow deposits that make up the bulk of the other fans in the Khumbu Himal. The CRN dates are tightly clustered; of the 14 samples that were taken from this surface across the study area, all but one was dated between 9.8 and $14.3 \mathrm{ka}$. The ages span the Younger Dryas Stadial, but no glacial advances are recognized in the Khumbu Himal anywhere near this time (Finkel et al. 2003). However, lack of evidence for Younger Dryas-age moraines does not necessarily suggest absence of a Younger Dryas glacial advance. It is possible that a glacial advance at $c .12 \mathrm{ka}$ did exist and that subsequent advances eroded the moraine ridges. Fluvial incision downvalley could have helped preserve the correlative surfaces. Alternatively, a major lake burst might have occurred at c. $12 \mathrm{ka}$, and the resulting flood formed extensive deposits throughout the Khumbu Himal, including Pangboche, Orsho and Dingboche. This may explain how vast fans could be deposited outside 'paraglacial times', which were once thought to exist for only hundreds of years following glacial retreat (Ballantyne 1995; Owen \& Sharma 1998). The potential long-term response of the Khumbu system to the new hydrological conditions associated with deglaciation, although speculative in this case, causes us to reconsider the potential temporal range of landscape response to deglaciation.

With the exception of $\mathrm{f}_{\mathrm{p} 3}(c .58 \mathrm{ka})$, no fan or terrace surfaces in the study area are older than Late Pleistocene. Fan deposits in the outwash plain of Khumbu glaciers rarely persist for more than $16 \mathrm{ka}$ before they are eroded away. The setting beneath a glacier front is subject not only to slope and weathering processes, but can also be affected by floods, debris flows, etc. All these processes reduce the likelihood that fans or terraces will survive long in this environment. The oldest landform dated by CRN methods in the study area is a $c .91 \mathrm{ka}$ moraine high above Duglha (Fig. 2: Finkel et al. 2003). This suggests that glaciofluvial landforms have not persisted for more than $c$. $100 \mathrm{ka}$ in the Khumbu Himal, because of fluvial, slope and weathering processes.

Supraglacial lakes are at present forming east of Chhukhung on the Imja Khola Glacier (Figs 2 and 13a) and at Gokyo on the Ngozumpa Glacier, $15 \mathrm{~km}$ due west of the terminus of the Khumbu Glacier (Benn et al. 2001). These lakes are related to historical glacial retreat from advanced positions of the LIA. Dead ice zone lakes build rapidly during the initial rapid glacial retreat associated with the end of glacial stages (Benn et al. 2001) and thus when dams fail the resulting glacial-lake outburst flood may be a causal mechanism of fan or terrace formation throughout the Imja Khola Valley. Proglacial lakes, such as the one currently building at the base of the Tsola Glacier (Figs. 2 and 13b), can lead to similar episodes of catastrophic sedimentation.

During deglaciation, high discharge and sediment loads promote strath terrace formation where bedrock is exposed. These same conditions in a wider valley can produce fan sequences. In a narrower, steeper portion of the valley, a smaller channel carrying a comparable discharge and sediment load results in higher bed velocities and thus favours strath formation (Foley 1980; Anderson 1994; Merritts et al. 1994; Personius 1995; Leland et al. 1998).

Incision rates calculated from strath terraces can be used as a proxy for the long-term denudation and uplift rates of a region, whereas the age of the terrace can yield a deglaciation age 

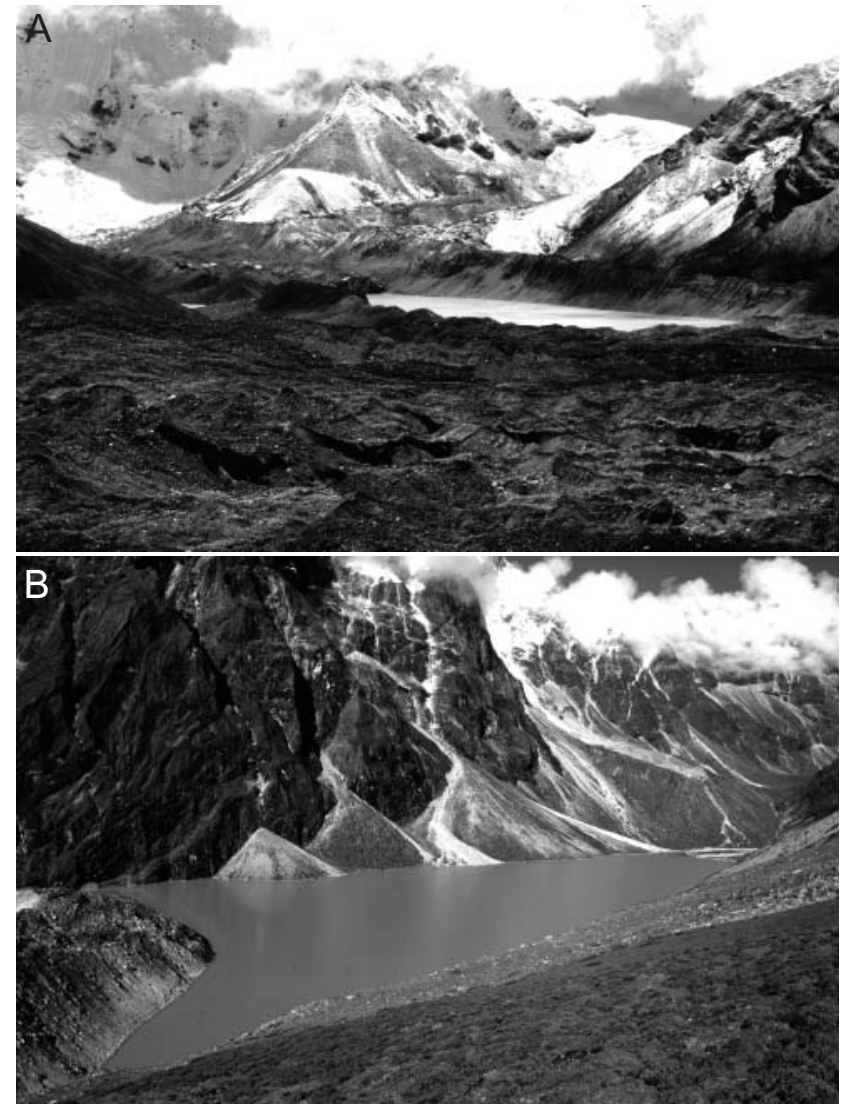

Fig. 13. Lakes forming at present in the Khumbu study area. (See Fig. 2 for locations.) (a) Glacial lake trapped in the maze of moraines and glaciers to the east of Chhukhung. Lake is $c .1 \mathrm{~km}$ in length. (b) Tsola Lake trapped behind the Tsola Glacier (left) and an abandoned Khumbu glacier moraine (right).

(Barnard et al. 2001). The older the strath terrace, the closer the derived incision rates will approximate the long-term uplift rate (Leland et al. 1998). The incision rates derived from four strath terraces in the Khumbu Himal, averaging $3.9 \mathrm{~mm} \mathrm{a}^{-1}$ (ranging from 3.4 to $4.3 \mathrm{~mm} \mathrm{a}^{-1}$ ), are consistent over the last $16 \mathrm{ka}$ (Table 2). This average rate is similar to the denudation rates calculated from other Himalayan regions that average c. $5.7 \mathrm{~mm} \mathrm{a}^{-1}$ (e.g. ranging from 0.3 to $15.9 \mathrm{~mm} \mathrm{a}^{-1}$ : Brunsden et al. 1981; Zeitler 1985; Valdiya \& Bartarya 1989; Burbank \& Beck 1991; Gardner \& Jones 1993; Burbank et al. 1996; Leland et al. 1998; Shroder et al. 1999; Barnard et al. 2001, 2004a, b; Vance et al. 2003). Burbank (2002) showed that erosion by rivers, landslides and glaciers can exceed $5 \mathrm{~mm} \mathrm{a}^{-1}$ and these rates can be sustained over time periods of the order of $10^{2}-10^{5}$ a. Mountain uplift rates in the Himalaya during the last $0.5 \mathrm{Ma}$ have been estimated at $1-3 \mathrm{~mm} \mathrm{a}^{-1}$ by Leland et al. (1998), based on CRN dating and apatite fission-track measurements from strath terraces in Nanga Parbat region of the NW Himalaya. Uplift rates have been estimated at $2-5 \mathrm{~mm} \mathrm{a}^{-1}$, during the last $7 \mathrm{ka}$, based on strath terrace dating in the middle gorge of the Indus River near Nanga Parbat (Burbank et al. 1996). Uplift results in the net lowering of base level and thus is a major factor driving incision. Leland et al. (1998) documented an acceleration of average bedrock incision rates during the last $15 \mathrm{ka}$ in Nanga Parbat, considered to be the locale of maximum incision rates in the Himalayas
(Zeitler et al., 2001), and attributed this acceleration to an increase in discharge and/or sediment load related to deglaciation in the surrounding mountains following the major glacial advances of the Last Glacial. They also noted a substantial increase in incision rates during the last $7 \mathrm{ka}$, from $1-6 \mathrm{~mm} \mathrm{a}^{-1}$ prior to $7 \mathrm{ka}$ to $9-12 \mathrm{~mm} \mathrm{a}^{-1}$.

Three of the strath terraces we dated have ages similar to those of the fans dated in this study and to three of the glacial stages of Finkel et al. (2003). These are $3.7 \mathrm{ka}$ (Thuklha Stage $3.6 \mathrm{ka}$; and at Orsho $4.4 \mathrm{ka}$ for $\mathrm{t}_{03}$ and $4.8 \mathrm{ka}$ for $\mathrm{t}_{04}$, and at Dingboche $4.1 \mathrm{ka}$ for $\mathrm{t}_{\mathrm{d} 1}$ and $4.9 \mathrm{ka}$ for $\mathrm{t}_{\mathrm{d} 2}$ ), $12.6 \mathrm{ka}$ (at Pangboche $12.0 \mathrm{ka}$ for $\mathrm{t}_{\mathrm{p} 7}$, at Orsho $11.0 \mathrm{ka}$ for $\mathrm{t}_{\mathrm{o} 6}$, and at Dingboche $13.2 \mathrm{ka}$ for $t_{\mathrm{d} 3}$ ) and $16.2 \mathrm{ka}$ (Pheriche II Stage $16.0 \mathrm{ka}$, and at Pangboche $16.8 \mathrm{ka}$ for $\mathrm{f}_{\mathrm{p} 2}$ ). This potential relationship between glacial stages and the formation of strath terraces and fans suggests that there is a glacial control on pulses of erosion and sedimentation downvalley. However, the strath terrace dated to $6.6 \mathrm{ka}$ (sample E91; Table 1) cannot be morphostratigraphically correlated to any of the glacial stages or fan and terrace surfaces at Pangboche, Orsho or Dingboche. We tentatively link the formation of this strath either with $\mathrm{t}_{\mathrm{p} 6}$ at Pangboche (c. $\left.8.1 \mathrm{ka}\right)$ or with the termination of the Chhukhung Stage (c. 9.2 ka). This discrepancy may be due to errors in the dating, periods of high discharge and sediment loads that are not related to glacier fluctuations, or an unrecognized glacial stage.

Large-scale sedimentation and erosion events would be expected to occur more frequently in the Dingboche area than further downvalley because the potential for flooding is higher in an area more directly affected by the varying fluctuations and outwash of numerous glaciers. The larger number of individual beds recorded in the sediment logs in the Dingboche terraces, as compared with the fans and terraces in the Orsho and Pangboche areas, which contain similar exposure thicknesses, demonstrate the greater frequency of events or distal deposits. The large existing volumes of the fan and terrace deposits indicate that these landforms may be the most stable location for the longterm storage of sediment. Therefore, the style of formation and erosion of fans and terraces in the Himalaya is largely controlled by their proximity to glacial fluctuations.

\section{Conclusions}

Fan and terrace formation occurred during five times in the Late Quaternary: c. $16 \mathrm{ka}$, c. $12 \mathrm{ka}, 8 \mathrm{ka}, 4 \mathrm{ka}$ and $1.5 \mathrm{ka}$. With the exception of the $12 \mathrm{ka}$ episode, these depositional events can be linked temporally and sedimentologically to the glacial stages defined by Finkel et al. (2003). Fans and terraces in the Khumbu Himal primarily comprise bouldery and cobbly diamicts deposited by debris flows and hyperconcentrated flows. This morphology and sedimentology suggest that incision, sediment transfer and deposition are driven by short-term variations in discharge and sediment load conditioned by glacial oscillations. Thus fan and terrace formation and incision are related to sporadic, catastrophic events that are intimately tied to rapid glacial fluctuations. Fans and terraces in other parts of the Himalaya probably respond in a similar fashion to those in the Khumbu Himal, resulting in common forms of landscape evolution. This suggests that our fan and terrace chronologies might be used for regional correlations throughout the monsoon-influenced Himalaya. Furthermore, the chronologies provide some of the first data to aid in quantifying the timing and rates of moraine denudation and sediment transfer within the Himalaya.

Longer-term rates of incision of the Khumbu Himal approximate to typical Himalayan uplift rates. Calculations of bedrock 
incision rates from the CRN dating of strath terraces in the Khumbu Himal are consistent with rates for other parts of the Himalaya, averaging c. $3.9 \mathrm{~mm} \mathrm{a}^{-1}$.

Funding for the field component of this project was provided by a grant from Sigma Xi. The cosmogenic radionuclide dating analysis was undertaken at the Lawrence Livermore National Laboratory (under DOE contract W-7405-ENG-48) as part of an IGPP/LLNL research grant and a Student Employee Graduate Research Fellowship. We thank the two referees for their helpful comments. Thanks to T. Phillips for drafting Figures 2, 3, 6 and 7 .

\section{References}

Anderson, R.S. 1994. Evolution of the Santa Cruz Mountains, California, through tectonic growth and geomorphological decay. Journal of Geophysical Research, 99, 20161-20179.

Anderson, R.S., RePKA, J.L. \& Dick, G.S. 1996. Explicit treatment of inheritance in dating depositional surfaces using in situ ${ }^{10} \mathrm{Be}$ and ${ }^{26} \mathrm{Al}$. Geology, 24, $47-51$.

AoKi, T. \& Imamura, M. 1999. Reconstructing the glacial chronology based on the ${ }^{10} \mathrm{Be}$ exposure age in the Khumbu GlacierEasterm Nepal Himalaya. In: Proceedings of the Korea-Japan/Japan-Korea Geomorphological Conference. 134-135.

Ballantyne, C.K. 1995. Paraglacial debris-cone formation on recently deglaciated terrain, western Norway. The Holocene, 5, 25-33.

Ballantyne, C.K. 2002. Paraglacial geomorphology. Quaternary Science Reviews, 21, 1935-2017.

Ballantyne, C.K. 2003. Paraglacial landsystems. In: Evans, D.J. (ed.) Glacial Landsystems. Edward Arnold, London, 432-461.

Barnard, P.L., Owen, L.A., Sharma, M.C. \& Finkel, R.C. 2001. Natural and human-induced landsliding in the Garhwal Himalaya of Northern India. Geomorphology, 40, 21-35.

Barnard, P.L., Owen, L.A. \& Finkel, R.C. 2004a. Style and timing of glacial and paraglacial sedimentation in a monsoonal-influenced high Himalayan environment, the upper Bhagirathi Valley, Garhwal Himalaya. Sedimentary Geology, 165, 199-221.

Barnard, P.L., Owen, L.A., Sharma, M.C. \& Finkel, R.C. 2004b. Late Quaternary landscape evolution of a monsoon-influenced high Himalayan valley, Gori Ganga, Nanda Devi, NE Garhwal. Geomorphology, 61, 91-110.

Benn, D.I. \& Evans, D.J. 1998. Glaciers and Glaciation. Arnold, London.

BENN, D.I. \& OwEN, L.A. 1998. The role of the Indian summer monsoon and the mid-latitude westerlies in Himalayan glaciation; review and speculative discussion. Journal of the Geological Society, London, 155, 353-364.

BenN, D.I., Wiseman, S. \& HandS, K.A. 2001. Growth and drainage of supraglacial lakes on debris-mantled Ngozumpa Glacier, Khumbu Himal, Nepal. Journal of Glaciology, 47, 626-638.

Beverage, J.P. \& Culbertson, J.K. 1964. Hyperconcentrations of suspended sediment. Journal of the Hydraulic Division, American Society of Civil Engineering, 90, 117-128.

Bishop, M.P., Shroder, J.F., Bonk, R. \& Olsenholler, J. 2002. Geomorphic change in high mountains: a western Himalayan perspective. Global and Planetary Change, 32, 311-329.

Brunsden, D., Jones, D.K.C., Martin, R.D. \& Doornkamp, J.C. 1981. The geomorphological character of the low Himalaya of Eastern Nepal. Zeitschrift für Geomorphologie, 37, 27-42.

Burbank, D.W. 2002. Rates of erosion and their implications for exhumation. Mineralogical Magazine, 66, 25-52.

Burbank, D.W. \& BECK, R.A. 1991. Rapid, long-term rates of denudation. Geology, 19, 1169-1172.

Burbank, D.W., Leland, J., Fielding, E., Anderson, R.S., Brozovic, N., Reid, M.R. \& DunCAN, C. 1996. Bedrock incision, rock uplift and threshold hillslopes in the northwestern Himalayas. Nature, 379, 505-510.

Cenderelli, D.A. \& Wohl, E.E. 2001. Peak discharge estimates of glacial-lake outburst floods and 'normal' climatic floods in the Mount Everest region, Nepal. Geomorphology, 40, 57-90.

Church, M.A. \& RYder, J.M. 1972. Paraglacial sedimentation; a consideration of fluvial processes conditioned by glaciation. Geological Society of America Bulletin, 83, 3059-3071.

Church, M.A. \& Slaymaker, O. 1989. Disequilibrium of Holocene sediment yield in glaciated British Columbia. Nature, 337, 452-454

CostA, J.E. 1988. Rheologic, geomorphic and sedimentologic differentiation of water floods, hyperconcentrated flows and debris flows. In: BAKER, V.R., Kochel, R.C. \& Patton, P.C. (eds) Flood Geomorphology. Wiley, New York, 113-122.
Coussat, P. \& Meunier, M. 1996. Recognition, classification and mechanical description of debris flows. Earth-Science Reviews, 40, 209-227.

Derbyshire, E. \& Owen, L.A. 1990. Quaternary alluvial fans in the Karakoram Mountains. In: RachocKI, A.H. \& ChURCH, M. (eds) Alluvial Fans: a Field Approach. Wiley, Chichester, 27-53.

Eyles, N., Dearman, W.R. \& Douglas, T.D. 1983. The distribution of glacial landsystems in Britain and North America. In: Eyles, N. (ed.) Glacial Geology. Pergamon, Oxford, 213-228.

Finkel, R.C., Owen, L.A., Barnard, P.L. \& Caffee, M.W. 2003. Beryllium-10 dating of Mount Everest moraines indicates a strong monsoonal influence and glacial synchroneity throughout the Himalaya. Geology, 31, 561-564.

Foley, M.G. 1980. Quaternary diversion and incision, Dearborn River, Montana. Geological Society of America Bulletin, 91, 2152-2188.

Fushimi, H. 1977. Glaciations in the Khumbu Himal (1). Seppyo, 39, 60-67.

Fushimi, H. 1978. Glaciations in the Khumbu Himal (2). Seppyo, 40, 71-77.

GARDNER, J.S. \& JoneS, N.K. 1993. Sediment transport and yield at the Raikot Glacier, Nanga Parbat, Punjab Himalaya. In: SHroder, J.F. (ed.) Himalaya to the Sea: Geology, Geomorphology and the Quaternary. Routledge, London, 184-197.

Hancock, G.S., Anderson, R.S., Chadwick, O.A. \& Finkel, R.C. 1999. Dating fluvial terraces with ${ }^{10} \mathrm{Be}$ and ${ }^{26} \mathrm{Al}$ profiles; application to the Wind River, Wyoming. Geomorphology, 27, 41-60.

Ives, J.D. 1986. Glacial Lake Outburst Floods and Risk Engineering in the Himalaya: a Review of the Langmoche Disaster, Khumbu Himal, 4 August 1985. International Centre for Integrated Mountain Development Occasional Paper, 5.

Iwata, S. 1976. Late Pleistocene and Holocene moraines in the Sagamartha (Everest) region, Khumbu Himal. Seppyo, 38, 109-114.

Kohl, C.P. \& Nishiızumi, K. 1992. Chemical isolation of quartz for measurement of in situ-produced cosmogenic nuclides. Geochimica et Cosmochimica Acta, 56, 3583-3587.

LAL, D. 1991. Cosmic ray labelling of erosion surfaces: in situ nuclide production rates and erosion rates. Earth and Planetary Science Letters, 104, 424-439.

Leland, J., Reid, M.R., Burbank, D.W., Finkel, R. \& Caffee, M. 1998. Incision and differential bedrock uplift along the Indus River near Nanga Parbat, Pakistan Himalaya, from ${ }^{10} \mathrm{Be}$ and ${ }^{26} \mathrm{Al}$ exposure age dating of straths. Earth and Planetary Science Letters, 154, 93-107.

MAIZELS, J.K. 1993. Lithofacies variations within sandar deposits: the role of runoff regime, flow dynamics and sediment supply characteristics. Sedimentary Geology, 85, 299-325.

Merritts, D.J., VincEnT, K.R. \& Wohl, E.E. 1994. Long river profiles, tectonism and eustasy: a guide to interpreting fluvial terraces. Journal of Geophysical Research, 99, 14031-14050.

Muller, F. 1958. Eight months of glacier and soil research in the Everest region. In: The Mountain World 1958-1959. Swiss Foundation for Alpine Research. George Allan and Unwin, London, 191-208.

Muller, F. 1980. Present and late Pleistocene equilibrium line altitudes in the Mt. Everest region - an application of glacier inventory. World Glacier Inventory, 126, 75-94.

Nepal Department of Hydrology and Meteorology 1993. Snow and Glacier Hydrology Year-book 1987-1992. Ministry of Water Resources, Kathmandu.

Nepal Department of Hydrology and Meteorology 1995. Snow and Glacier Hydrology Section, Year-book 1994, Supplement III. Ministry of Water Resources, Kathmandu.

Nepal Department of Hydrology and Meteorology 1996. Snow and Glacier Hydrology Section, Year-book 1994, Supplement IV. Ministry of Water Resources, Kathmandu.

Nepal Department of Hydrology and Meteorology 1997. Snow and Glacier Hydrology Section, Year-book 1995, Supplement V. Ministry of Science and Technology, Kathmandu.

Nishizzumi, K., Winterer, E.L., Kohl, C.P., Lal, D., Arnold, J.R., Klein, J. \& Middleton, R. 1989. Cosmic ray production rates of ${ }^{10} \mathrm{Be}$ and ${ }^{26} \mathrm{Al}$ in quartz from glacially polished rocks. Journal of Geophysical Research, 94, 1790717915.

Owen, L.A. \& Lehmкuhl, F. 2000. Late Quaternary Glaciation and Paleoclimate of the Tibetan Plateau and Bordering Mountains. Quaternary International, $65 / 66$.

Owen, L.A. \& Sharma, M.C. 1998. Rates of paraglacial fan formation in the Garhwal Himalaya: implications for landscape evolution. Geomorphology, 26, 171-184

Owen, L.A. \& ZHOU, S. 2002. Late Quaternary Glaciation in the High Mountains of Central Asia: a Contribution of IGCP Working Group 5 of Glacial Commission of INQUA. Quaternary International, 97-98.

Owen, L.A., Benn, D.I. \& Derbyshire, E. ET AL. 1995. The geomorphology and landscape evolution of the Lahul Himalaya, Northern India. Zeitscrift für Geomorphologie, 39, 145-174.

Owen, L.A., Derbyshire, E. \& Fort, M. 1998. The Quaternary glacial history of the Himalaya. Quaternary Proceedings, 6, 91-120. 
Owen, L.A., Gualtieri, L., Finkel, R.C., Caffee, M.W., Benn, D.I. \& Sharma, M.C. 2001. Cosmogenic radionuclide dating of glacial landforms in the Lahul Himalaya, northern India: defining the timing of late Quaternary glaciation. Journal of Quaternary Science, 16, 555-563.

Owen, L.A., Finkel, R.C. \& CAFfee, M.W. 2002a. A note on the extent of glaciation in the Himalaya during the global Last Glacial Maximum. Quaternary Science Reviews, 21, 147-158.

Owen, L.A., Finkel, R.C., Caffee, M.W. \& Gualtieri, L. 2002b. Timing of multiple glaciations during the Late Quaternary in the Hunza Valley, Karakoram Mountains, Northern Pakistan: defined by cosmogenic radionuclide dating of moraines. Geological Society of America Bulletin, 114, 593-604.

Personius, S.F. 1995. Late Quaternary stream incision and uplift in the forearc of the Cascadia subduction zone, western Oregon. Journal of Geophysical Research, 100, 20193-20210.

Pierson, T.C. \& CostA, J.E. 1987. A rheologic classification of subaerial sediment-water flows. Geological Society of America, Reviews in Engineering Geology, 7, 1-12.

Pratt, B., Burbank, D.W., Heimsath, A. \& Ojha, T. 2002. Impulsive alluviation during early Holocene strengthened monsoons, central Nepal Himalaya. Geology, 30, 911-914.

Richards, B.W., Benn, D.I., Owen, L.A., Rhodes, E.J. \& Spencer, J.Q. 2000. Timing of Late Quaternary glaciations south of Mount Everest in the Khumbu Himal, Nepal. Geological Society of America Bulletin, 112, 1621-1632.

RYDER, J.M. 1971a. Some aspects of the morphology of paraglacial alluvial fans in south-central British Columbia. Canadian Journal of Earth Science, 8, $1252-1264$.

RYDER, J.M. 1971b. The stratigraphy and morphology of paraglacial alluvial fans in south-central British Columbia. Canadian Journal of Earth Sciences, 8, 279-298.

Schultz, A.W. 1984. Subaerial debris-flow deposition in the Upper Paleozoic Cutler Formation, W. Colorado. Journal of Sedimentary Petrology, 54, 759-772.

Shroder, J.F., Scheppy, R.A. \& Bishop, M.P. 1999. Denudation of small alpine basins, Nanga Parbat Himalaya, Pakistan. Arctic, Antarctic, and Alpine Research, 31, 121-127.

Sirocko, F., Sarnthein, M., Lange, H. \& Erlenkeuser, H. 1991. Atmospheric summer circulation and coastal upwelling in the Arabian Sea during the Holocene and last glaciation. Quaternary Research, 36, 72-93.

Sohn, Y.K., RheE, C.W. \& Kim, B.K. 1999. Debris flow and hyperconcentrated flood-flow deposits in an alluvial fan, northwestern part of the Cretaceous Yongdong Basin, Central Korea. Journal of Geology, 107, 111-132.

StONE, J.O. 2000. Air pressure and cosmogenic isotope production. Journal of Geophysical Research, 105, 23753-23759.

Svendsen, J., Stollhofen, H., Krapf, C.B. \& Stanistreet, I.G. 2003. Mass and hyperconcentrated flow deposits record dune damming and catastrophic breakthrough of ephemeral rivers, Skeleton Coast Erg, Namibia. Sedimentary Geology, 160, 7-31.

Valdiya, K.S. \& Bartarya, S.K. 1989. Problem of mass movements in a part of the Kumaun Himalaya. Current Science, 58, 486-491.

Vance, D., Bickle, M., Ivy-Ochs, S. \& KubiK, P.W. 2003. Erosion and exhumation in the Himalaya from cosmogenic isotope inventories of river sediments. Earth and Planetary Science Letters, 206, 273-288.

Watanabe, T., Dali, L. \& Shiraiwa, T. 1998. Slope denudation and the supply of debris to cones in Langtang Himal, Central Nepal Himalaya. Geomorphology, 26, 185-197.

Williams, V.S. 1983. Present and former equilibrium-line altitudes near Mt Everest, Nepal and Tibet. Arctic and Alpine Research, 15, 201-211.

Zeitler, P.K. 1985. Cooling history of the Northwest Himalayas, Pakistan. Tectonics, 4, 127-141.

Zeitler, P.K., Meltzer, A.S. \& Koons, P. et AL. 2001. Erosion, Himalayan geodynamics, and the geomorphology of metamorphism. GSA Today, 11, 4-9.

ZiELINSKI, T. \& VAN LOON, A.J. 1996. Characteristics and genesis of morainederived flowtill varieties. Sedimentary Geology, 101, 119-143.

Zimmermann, M., Bichsel, M. \& Kienholz, H. 1986. Mountain hazards mapping in the Khumbu Himal, Nepal, with prototype map, scale 1:50000. Mountain Research and Development, 6, 29-40. 